\title{
Capital Structure around the World: The Roles of Firm- and Country-Specific Determinants
}

\author{
Abe de Jong, Rezaul Kabir and Thuy Thu Nguyen
}

\begin{tabular}{|l|l|}
\hline \multicolumn{2}{|l|}{ ERIM REPORT SERIES RESEARCH IN MANAGEMENT } \\
\hline ERIM Report Series reference number & ERS-2007-058-F\&A \\
\hline Publication & September 2007 \\
\hline Number of pages & 41 \\
\hline Persistent paper URL & \\
\hline Email address corresponding author & tnguyen@rsm.nl \\
\hline Address & Erasmus Research Institute of Management (ERIM) \\
& RSM Erasmus University / Erasmus School of Economics \\
& Erasmus Universiteit Rotterdam \\
& P.O.Box 1738 \\
& 3000 DR Rotterdam, The Netherlands \\
& Phone: $\quad+31104081182$ \\
& Fax: $\quad+31104089640$ \\
& Email: info@erim.eur.nl \\
& Internet: $\quad$ www.erim.eur.nl \\
\hline
\end{tabular}

Bibliographic data and classifications of all the ERIM reports are also available on the ERIM website: www.erim.eur.nl 
ERASMUS RESEARCH INSTITUTE OF MANAGEMENT

REPORT SERIES

RESEARCH IN MANAGEMENT

\begin{tabular}{|l|l|}
\hline \multicolumn{2}{|l|}{ ABSTRACT AND KEYWORDS } \\
\hline Abstract & $\begin{array}{l}\text { We analyze the importance of firm-specific and country-specific factors in the leverage choice of } \\
\text { firms from } 42 \text { countries around the world. Our analysis yields two new results. First, we find that } \\
\text { firm-specific determinants of leverage differ across countries, while prior studies implicitly } \\
\text { assume equal impact of firm-specific factors. Second, although we concur with the conventional } \\
\text { direct impact of country-specific factors on the capital structure of firms, we show that there is an } \\
\text { indirect impact because country-specific factors also influence the roles of firm-specific } \\
\text { determinants of leverage. }\end{array}$ \\
\hline Free Keywords & Capital structure, leverage, firm-specific factors, country-specific factors, international evidence \\
\hline Availability & $\begin{array}{l}\text { The ERIM Report Series is distributed through the following platforms: } \\
\text { Academic Repository at Erasmus University (DEAR), DEAR ERIM Series Portal } \\
\text { Social Science Research Network (SSRN), SSRN ERIM Series Webpage } \\
\text { Research Papers in Economics (REPEC), REPEC ERIM Series Webpage }\end{array}$ \\
\hline Classifications & $\begin{array}{l}\text { The electronic versions of the papers in the ERIM report Series contain bibliographic metadata } \\
\text { by the following classification systems: } \\
\text { Library of Congress Classification, (LCC) } \underline{\text { LCC Webpage }} \\
\text { Journal of Economic Literature, (JEL), JEL Webpage } \\
\text { ACM Computing Classification System CCS Webpage } \\
\text { Inspec Classification scheme (ICS), ICS Webpage }\end{array}$ \\
\hline
\end{tabular}




\title{
Capital structure around the world: The roles of firm- and country-specific determinants
}

\author{
Abe de Jong \\ RSM Erasmus University \\ (ajong@rsm.nl) \\ Rezaul Kabir \\ University of Stirling \\ (r.kabir@stir.ac.uk) \\ Thuy Thu Nguyen \\ RSM Erasmus University \\ (tnguyen@rsm.nl)
}

September 2007

JEL classification: F30, G10, G32

Keywords: Capital structure, leverage, firm-specific factors, country-specific factors, international evidence

The authors would like to thank Leo de Haan, Ingolf Dittmann, Daniela Fabbri, Cesario Mateus, Peter Roosenboom, Mathijs van Dijk, Marno Verbeek, two anonymous referees, seminar participants at RSM Erasmus University, University of Stirling, and the participants at the European Finance Association Annual Meeting (Zurich) and the Financial Management Association Annual Meeting (Salt Lake City) for their helpful comments. 


\title{
Capital structure around the world:
}

\section{The roles of firm- and country-specific determinants}

\begin{abstract}
We analyze the importance of firm-specific and country-specific factors in the leverage choice of firms from 42 countries around the world. Our analysis yields two new results. First, we find that firm-specific determinants of leverage differ across countries, while prior studies implicitly assume equal impact of firm-specific factors. Second, although we concur with the conventional direct impact of country-specific factors on the capital structure of firms, we show that there is an indirect impact because country-specific factors also influence the roles of firm-specific determinants of leverage.
\end{abstract}




\section{Introduction}

Prior research (e.g. Demirgüç-Kunt and Maksimovic, 1999; Booth, Demirgüç-Kunt and Maksimovic, 2001; Claessens, Djankov and Nenova, 2001; Bancel and Mittoo, 2004) finds that a firm's capital structure is not only influenced by firm-specific factors but also by countryspecific factors. In this study, we demonstrate that country-specific factors can affect corporate leverage in two ways. On the one hand, these factors can influence leverage directly. For example, a more developed bond market facilitating issue and trading of public bonds may lead to the use of higher leverage in a country, while a developed stock market has the opposite effect. On the other hand, we show that country-specific factors can also influence corporate leverage indirectly through their impact on firm-specific factors' roles. For example, although the developed bond market of a country stimulates the use of debt, the role of asset tangibility as collateral in borrowing will be rather limited for firms in the same country. In other words, country-characteristics may explain why in one country a firm's tangibility affects leverage, but not in another country. Previous studies have not systematically investigated these indirect effects.

International studies comparing differences in the capital structure between countries started to appear only during the last decade. An early investigation of seven advanced industrialized countries is performed by Rajan and Zingales (1995). They argue that although common firm-specific factors significantly influence the capital structure of firms across countries, several country-specific factors also play an important role. Demirgüç-Kunt and Maksimovic (1999) compare capital structure of firms from 19 developed countries and 11 developing countries. They find that institutional differences between developed and developing countries explain a large portion of the variation in the use of long-term debt. They also observe that some institutional factors in developing countries influence the leverage of large and small 
firms differently. Several recent studies on the field have indicated that even among developed economies like the U.S. and European countries, the financing policies and managers' behavior are influenced by the institutional environment and international operations (see, for example, Graham and Harvey, 2001; Bancel and Mittoo, 2004; and Brounen, De Jong and Koedijk, 2006).

The literature specifically discusses only the direct impact of country characteristics on leverage. In an analysis of ten developing countries, Booth et al. (2001) find that capital structure decisions of firms in these countries are affected by the same firm-specific factors as in developed countries. However, they find that there are differences in the way leverage is affected by country-specific factors such as GDP growth and capital market development. They conclude that more research needs to be done to understand the impact of institutional factors on firms' capital structure choices. The importance of country-specific factors in determining crosscountry capital structure choice of firms is also acknowledged by Fan et al. (2006) who analyze a larger sample of 39 countries. They find a significant impact of a few additional countryspecific factors such as the degree of development in the banking sector, and equity and bond markets. In another study of 30 OECD countries, Song and Philippatos (2004) report that most cross-sectional variation in international capital structure is caused by the heterogeneity of firm-, industry-, and country-specific determinants. However, they do not find evidence to support the importance of cross-country legal institutional differences in affecting corporate leverage. Giannetti (2003) argues that the failure to find a significant impact of country-specific variables may be due to the bias induced in many studies by including only large listed companies. She analyzes a large sample of unlisted firms from eight European countries and finds a significant influence on the leverage of individual firms of a few institutional variables such as creditor protection, stock market development and legal enforcement. Similarly, Hall et al. (2004) 
analyze a large sample of unlisted firms from eight European countries. They observe crosscountry variation in the determinants of capital structure and suggest that this variation could be due to different country-specific variables.

A remarkable feature of existing studies on international capital structure is the implicit assumption that the impact of firm-specific factors on leverage is equal across countries (see for example Booth et al., 2001; Giannetti, 2003; Deesomsak et al., 2004; Song and Philippatos, 2004; and Fan et al., 2006). By reporting the estimated coefficients for firm-specific determinants of leverage per country, these papers, on the one hand, acknowledge that the impact of firm-level determinants does differ in terms of signs, magnitudes and significance levels. On the other hand, in the analysis of country-specific determinants of corporate leverage, these papers also make use of country dummies in pooled firm-year regressions, thus forcing the firm-specific coefficients to have the same value. With an extremely large number of firm-year observations, it is more likely for this procedure to produce statistically significant results for many country-specific variables. But, utilizing an alternative regression framework where a single average capital structure for each country is used as an observation, one hardly finds strong evidence on this issue (e.g. Booth et al., 2001; Demirgüç-Kunt and Maksimovic, 1999). As an additional contribution of our paper, we show the invalidity of this implicit assumption. Our analysis without imposing such restriction thus provides a more reliable analysis on the importance of country-specific variables.

The study encompasses a large number of countries (42 in total) from every continent for the period 1997-2001. We construct a database of nearly 12,000 firms (about 60,000 firm-year observations). All types of firms - large and small - are included as long as a reasonable amount of data is available. We analyze the standard firm-specific determinants of leverage like firm size, asset tangibility, profitability, firm risk and growth opportunities. Besides, we incorporate a 
large number of country-specific variables in our analysis, including legal enforcement, shareholder/creditor right protection, market/bank-based financial system, stock/bond market development and growth rate in a country's gross domestic product (GDP).

We first make a detailed comparative analysis of the impact of various firm-specific factors. We find across a large number of countries that the impact of some factors like tangibility, firm size, risk, profitability and growth opportunities is strong and consistent with standard capital structure theories. Our study shows that, in terms of firm-specific determinants of leverage, capital structure theories do explain the corporate leverage choice in a large number of countries. Using a model with several firm-specific explanatory variables, we find a relatively large explanatory power of leverage regressions in most countries. However, a few determinants remain insignificant, and in some countries one or two coefficients are significant with an unexpected sign. Performing a simple statistical test, we reject the hypothesis that firm-specific coefficients across countries are equal. It indicates that the often-made implicit assumption of equal firm-level determinants of leverage across countries does not hold.

In the analysis of the direct impact of country-specific factors, we observe that certain factors like GDP growth rate, bond market development and creditor right protection significantly explain the variation in capital structure across countries. Moreover, we find considerable explanatory power of country-specific variables beyond firm-specific factors. We then proceed to measure the indirect impact of country-specific variables. The results consistently show the importance of country factors as we document significant effects of these via firm-specific determinants. For example, we observe that in countries with a better law enforcement system and a more healthy economy, firms are not only likely to take more debt, but the effects of some firm-level determinants of leverage such as growth opportunities, profitability and liquidity are also reinforced. Our findings indicate that the conventional 
theories on capital structure, developed using listed firms in the United States as a role model, work well in similar economies with developed legal environment and high level of economic development. The indirect impact analysis also indicates that firm-specific variables are significantly influenced by several country-specific variables but in different ways.

\section{Data}

Firm-specific and country-specific determinants are the two major types of variables that we take into account when analyzing the impacts on firms' leverage choice.

The firms in our sample cover 42 countries that are equally divided between developed and developing countries. ${ }^{1}$ Data for leverage and firm-specific variables are collected from COMPUSTAT Global database. We exclude financial firms and utilities. Data on countryspecific variables are collected from a variety of sources, mainly World Development Indicators files and Financial Structure Database of the World Bank. Few country-specific variables are taken from previous studies including La Porta et al. (1998), Claessens and Klapper (2002) and Berkowitz et al. (2003).

Our sample period covers the years 1997-2001. The selection of a time-period involves a trade-off between the number of countries that can be included in the study and the availability of enough firm-specific data. Whenever needed, we resort to some other sources to collect any missing data. It is still impossible to obtain data for each and every variable from all 42 countries during this time period. The final sample consists of 59,225 observations on 11,845 firms. Even though we aim to keep the number of countries high enough and also maintain a

\footnotetext{
${ }^{1}$ The choice of countries in the sample depends on the availability of firm-level financial data in Compustat Global. We take countries that have the highest numbers of observations in the period of study and exclude those with less than 10 firms per year. The categorization of a country into developing and emerging economy is based on Bekaert and Harvey (2003) and S\&P emerging market indices.
} 
reasonable number of firms, our dataset has unavoidably a limited number of firms in a few countries. $^{2}$

In order to calculate the leverage ( $L E V)$ ratio of a firm, we adopt the following widelyused measure: the book value of long-term debt (item\#106, Compustat Global database) over market value of total assets which is calculated as book value of total assets (item\#89) minus book value of equity (item\#146) plus market value of equity (item\#MKVAL). We use the longterm debt ratio following Titman and Wessels (1998), Demirgüç-Kunt and Maksimovic (1999), Booth et al. (2001), and Hall et al. (2004). ${ }^{3}$ Since the short-term debt consists largely of trade credit which is under the influence of completely different determinants, the examination of total debt ratio is likely to generate unreliable results.

The firm-specific determinants of leverage we use are also selected from prior studies and are defined as follows. TANG: Tangibility is defined as net fixed assets (item\#76) over book value of total assets. RISK: Business risk is defined as the standard deviation of operating income (item\#14) over book value of total assets during the sample period. SIZE: Firm size is defined as the natural logarithm of total sales (item\#1). TAX: Tax rate of firms is the average tax rate of the year directly extracted from COMPUSTAT Global (item\#TR). ${ }^{4}$ GROWTH: Growth opportunity is defined as the market value of total assets over book value of total assets. PROFIT: Profitability is defined as operating income over book value of total assets. LIQUID: Liquidity is defined as total current assets (item\#75) divided by total current liabilities

\footnotetext{
${ }^{2}$ Excluding these countries with relatively fewer numbers of firms does not change the conclusions of our analysis. ${ }^{3}$ Papers that use total debt ratios only include Rajan and Zingales (1995) and Deesomsak et al (2004). However, the studies that investigate both long-term and total debt ratio (e.g. Wald, 1999; Giannetti, 2003; Fan et al., 2006) generally find similar results for both measures. We also perform robustness checks by defining long-term debt in terms of book value of total assets and find almost no contradictory results.

${ }^{4}$ We use effective tax rates instead of marginal tax rates, because our explanatory variable concerns levels of debt, whereas the simulated marginal tax rates serve to explain incremental change in debt rather than the debt level itself.
} 
(item\#104). ${ }^{5}$ Several industry dummies are included as additional control variables to check the robustness of our results. ${ }^{6}$

Table 1 presents mean and median values of leverage and other firm-specific factors from all 42 countries during 1997-2001. For the sample of 42 countries, the mean long-term debt ratio is $12.9 \%$, while the median is $11.9 \%$.

[Insert Table 1 about here]

Previous studies analyze long-term leverage ratios across a limited number of countries for the period of 1980s and 1990s and tend to observe a lower leverage in emerging economies. In this study, we observe a wide-ranging pattern of leverage around the world. Many industrialized countries have a median leverage ratio of less than $10 \%$ (e.g. Australia, Austria, Belgium, France, Germany, Greece, Italy, Japan, The Netherlands, Sweden and the UK). With respect to emerging economies, we also observe very low leverage in some economies, such as China, Malaysia, Poland and Turkey. However, there are some developing countries with high long-term debt ratio (above 15\%), such as Argentina, India and Korea.

Table 1 also presents summary statistics of firm characteristics per country. For example, we observe that countries with low median tax rates are Hong Kong, Taiwan and Thailand; those with high rates include France, Germany, Italy, Japan, New Zealand and the US. Countries with the lowest values of asset tangibility are France, Germany, Italy, Sweden and

\footnotetext{
${ }^{5}$ Potential measurement errors in calculating firm-specific variables can be expected as we assume that the countries in our sample apply similar accounting standards.

${ }^{6}$ The following industry groups are considered in our analysis: Agriculture, forestry, fishing and resources (SIC code 0100 - 1499); Construction (SIC code 1500 - 1799); Food (SIC code 2000 - 2099); Tobacco, textiles, wood and furniture (SIC code 2100 - 2599); Paper, printing and publishing (SIC code 2600 - 2799); Chemicals, pharmaceuticals, and petroleum (SIC code 2800 - 2999); Rubber, leather, and stone (SIC code 3000 - 3299); Metal, machinery and other manufacturing (SIC code 3300 - 3599 and 3700 - 3999); Electronics (SIC code 3600 3699); and Transportation, trade and services (SIC code 4000 - 5999 and 6500 - 8999). Inclusion of these industry dummies does not yield a materially different result.
} 
US, while those with the highest values are Argentina, Chile, Croatia, Mexico and Pakistan. Among all firm-specific variables, the values of profitability exhibit the lowest variation.

We make use of an array of country-specific variables in our analysis of international capital structure. We consider a number of variables characterizing the macro-economic, legal and financial development of countries. These include bond and stock market structure, capital formation rate and GDP growth rate. The selection of some other country-specific variables related to corporate governance is mainly based on La Porta et al. (1998) and Claessens et al. $(1999)^{7}$, proxying a country's legal enforcement, shareholder/creditor right protection and market/bank-based financial system. Table 2 provides details on definitions, data sources and statistics of all country-specific variables.

[Insert Table 2 about here]

There is a problem of multi-collinearity arising from high correlations between several country-specific variables. ${ }^{8}$ Therefore, we construct two new variables to use as alternatives in the regression analysis. These new variables are: (1) STDMKTSTOCK, describing the level of stock market orientation of countries, calculated as the average of normalized values of MKTBASE and STOCK; and (2) STDENFOR, indicating the development of countries' legal enforcement system, calculated as the average of normalized values of JUDICIAL, RULE, LEGAL and CORRUP. The details on these variables are also presented in Table 2.

\footnotetext{
${ }^{7}$ These variables, associated with 1982-1995 (La Porta et al., 1998) and 1996-1999 (Claessens et al., 1999), usually remain relatively stable enough over different years.

${ }^{8}$ The correlation between MKTBASE and STOCK is 0.40 . The pair-wise correlations between JUDICIAL, RULE, LEGAL and CORRUP are $0.73,0.86,0.86,0.96$ and 0.97 , respectively.
} 


\section{Impact of firm-specific factors}

\subsection{Hypotheses}

Table 3 summarizes the hypotheses for the firm-specific effects. The table also includes the hypotheses for the equal firm-coefficient tests, which will be described in Section 3.2, and the hypotheses for the country-specific effects, which will be discussed in Section 4.1.

[Insert Table 3 about here]

Booth et al. (2001) observe that capital structures of firms are usually explained by several variables arising out of static trade-off, agency and information asymmetry considerations. In a static trade-off framework, the firm is viewed as setting a target debt-toassets ratio and moving towards it. In particular, the firm's capital structure moves towards targets that involve the trade-off between bankruptcy-related costs and tax advantages. With respect to the bankruptcy costs, we expect that these costs have a negative impact on leverage, and one can use the following proxy variables: asset tangibility (TANG) (higher tangibility of assets indicates lower risk for the lender as well as reduced direct costs of bankruptcy - see hypothesis $F 1$ in Table 3), firm risk (RISK) (higher risk indicates higher volatility of earnings and higher probability of bankruptcy - hypothesis F2), and firm size (SIZE) (an inverse proxy for the probability of bankruptcy whereby larger firms are less likely to face financial distress and bankruptcy - hypothesis F3). In order to examine the influence of taxation on leverage, which is expected to be positive, Fan et al. (2006) suggest using the effective tax rate (TAX) as a proxy (hypothesis F4).

Agency conflicts between stockholders and bondholders arise from asset-substitution and underinvestment. In order to minimize these conflicts firms with high growth opportunities 
go for lower leverage, thus seeking equity financing for their new projects instead of debt financing. Growth opportunities $(G R O W T H)$ are thus expected to be negatively associated with firms' leverage (hypothesis F5). Once again, tangibility can be used as a proxy for collateralization which is expected to be positively related to leverage.

The asymmetric information or pecking-order view suggests that firms follow a specific hierarchy in financing: firms prefer internal to external financing. If external finance is required, a firm issues the safest security first. That is, it first issues debt, then possibly hybrid securities such as convertible bonds, and equity only as a last resort. For testing the firm-specific determinants using information asymmetry considerations, it is common to use variables like profitability (PROFIT) (more profitable firms will have less leverage - hypothesis F6), firm size (smaller firms are expected to be financed less by debt because of the relatively larger information asymmetry problem), and liquidity (LIQUID) (accumulated cash and other liquid assets serve as internal source of fund and will be used first instead of debt - hypothesis F7).

\subsection{Methodology}

In the analysis of firm-specific determinants of leverage we test the conventional theoretical framework on capital structure choice of firms. We run firm-level ordinary-leastsquares regressions with leverage as the dependent variable and country's firm-specific factors as explanatory variables for each of the 42 countries in our data set as follows:

$$
\begin{aligned}
L E V_{i j}= & \beta_{0 j}+\beta_{1 j} \text { TANG }_{i}+\beta_{2 j} \text { RISK }_{i}+\beta_{3 j} \operatorname{SIZE}_{i}+\beta_{4 j} \text { TAX }_{i}+\beta_{5 j} \text { GROWTH }_{i}+\beta_{6 j} \text { PROFIT }_{i}+ \\
& +\beta_{7 j} \text { LIQUID }_{i}+\varepsilon_{i}
\end{aligned}
$$

where $i$ denotes an individual firm and $j$ denotes a country. This is equivalent to running a pooled regression of firm-specific factors, taking into account country dummies. However, our 
method yields more meaningful results since it reports the explanatory power of regression separately for each country.

Next, we conduct a few statistical tests. First, we test the null hypothesis that each firmspecific coefficient is equal across countries. The procedure includes seven different tests to examine whether one or more of the seven firm-specific coefficients, namely tangibility (hypothesis $E C 1)$, business risk (EC2), firm size (EC3), taxation (EC4), growth opportunities (EC5), profitability (EC6) and liquidity (EC7), have the same value for all countries in the sample. ${ }^{9}$ To conduct these tests, we make use of an unrestricted regression model (where all coefficients are allowed to vary across countries), and seven restricted models (e.g. for tangibility null hypothesis, we restrict that the tangibility coefficients are the same for all countries, but other coefficients of business risk, firm size, etc. can vary).

Second, using a similar approach, we test the null hypothesis that all firm-specific coefficients of 42 countries have the same value (hypothesis EC8). In this case, our single restricted model of regression imposes that all seven firm-specific coefficients can not vary at all. This particular test is more important because it allows one to decide whether it is acceptable to use a single model for firms in all countries. In other words, only if $E C 8$ is not rejected, one can assume that firm-specific coefficients are the same across countries. The former tests (from $E C 1$ to $E C 7)$ provide additional evidence to further confirm the rejection or acceptance of $E C 8$, and in case of EC8 rejection, they help to point out which firm-specific factors may largely influence such a rejection.

The tests are related to the joint test of significance of regression coefficients described in Verbeek (2004, p.27). The test statistic is defined as:

\footnotetext{
${ }^{9}$ These hypotheses are summarized in Table 3.
} 


$$
f=\frac{\left(S_{R}-S_{U R}\right) / J}{S_{U R} /(N-K)}
$$

where $N$ is the number of observations, $J$ is the number of regressors omitted in the restricted models, $K$ is the number of regressors remaining in the restricted models including the intercept, and $S_{R}$ and $S_{U R}$ denote the sum-squared-residuals of the restricted and unrestricted models, respectively. For each measure of leverage, using the Seemingly Unrelated Regression (SUR) estimation method, we get $S_{U R}$ by adding all sum-squared-residuals (SSR) from all the equations for firm-specific determinants of leverage (as specified in Equation (1)). For $S_{R}$ in each test (still using SUR), we add the SSR from the restricted equations in the system with respective assumptions that the relevant coefficients are the same across countries. The values of $f$-statistic provide evidence whether to reject or not the hypotheses.

\subsection{Results}

We start our discussion of the results with a country-by-country analysis of firm-specific determinants of leverage. We run regressions to explain leverage from firm-specific factors as shown in Equation (1). The results are reported in Table 4.

[Insert Table 4 about here]

We find that almost all coefficients of tangibility are statistically significant and consistent with theoretical proposition (hypothesis F1). The cross-sectional regressions yield as many as 36 significant positive coefficients for tangibility. In general, firm-level data in our sample serve the framework put forward by Jensen and Meckling (1976) on the shareholderbondholder conflict. If a firm has a high fraction of tangible assets, then these assets can be used 
as collateral, mitigating the lender's risk. Hence, a large fraction of tangible assets is expected to be associated with high leverage, and in case of bankruptcy, the value of tangible assets should be higher than that of intangibles.

Similar to tangibility results, we find 21 positively significant coefficients for firm size. The finding in half of the countries in our sample is in line with the hypothesis that larger firms have more debt (hypothesis F3). Since these firms are usually more diversified and have more stable cash flows, they can afford higher levels of leverage. Firm size can also be interpreted as a reverse proxy for bankruptcy costs. With respect to firm risk, there are only 14 significantly negative regression coefficients (hypothesis F2). Mixed results on this variable are also found in previous studies. The use of a very long period might provide a more precise proxy for risk factor.

We observe that the impact of corporate taxation on leverage choice of firms yields statistically significant coefficients in ten countries. However, only two out of ten significant coefficients are positive (hypothesis F4). MacKie-Mason (1990) notes that the reason why most studies fail to find plausible or significant tax effects on financing behavior is that the debt/equity ratios are the cumulative result of years of separate decisions and tax shields have a negligible effect on the marginal tax rate for most firms. In this study using global data, this observation seems to have a high relevance.

Growth opportunities yield 24 negative and significant coefficients. This negative relationship between growth opportunities and corporate leverage tends to support the agency theory (hypothesis F5). Firms with brighter growth opportunities in the future prefer to keep leverage low so they will not give up profitable investments because of the wealth transfer from shareholders to creditors. 
As for the impact of profitability, our findings are consistent with the asymmetric information theory which suggests that firms first use retained earnings for new investments and then move to debt and equity, if necessary (hypothesis F6). The expected negative relation between profitability and leverage is found in 25 countries. Finally, there are limited significant results for liquidity although conventional theories suggest a negative relation between liquidity and leverage (hypothesis F7). Most of significant negative coefficients belong to advanced economies. Overall, the general finding from Table 4 is in favor of the view that the corporate sector's conditions in more developed countries are likely to meet the hypothetical requirements needed for the conventional theories in capital structure.

An important question then arises: are firm-specific determinants of leverage different across countries? As argued earlier, it is meaningful to conduct additional analysis on the impact of country-specific determinants only after answering this question. If the firm-specific coefficients do not differ significantly across countries, we can apply one model for all firms in the world, similar to prior studies (Booth et al., 2001; Deesomsak et al., 2004; Song and Philippatos, 2004; and Fan et al, 2006). Otherwise, the procedure of pooling firms from different countries into one regression model wrongly forces different firm-specific coefficients to be equal.

In order to test the hypotheses that each of these seven firm-specific coefficients is equal across countries and that all firm-specific coefficients across countries are equal, we utilize an $f$ test of the set-up described earlier in the methodology section. The estimates for seven firmspecific determinants per country are already provided in Table 4 . The test results are presented in Table 5.

[Insert Table 5 about here] 
For the tests involving each firm-specific coefficient $(E C 1, E C 2, \ldots, E C 7)$, we can reject the null hypotheses, except for RISK coefficients. For the relatively more important test (EC8), the calculated value of the $f$-statistic is 5.38 . It provides a strong statistical evidence to reject the null hypothesis that all firm-specific coefficients are simultaneously equal for 42 countries in our sample. ${ }^{10}$ The result implies that it is not valid to construct a model with a single pool of all companies in the world and test the impact of country-specific factors assuming that crosscountry firm-specific determinants are equal. The result also suggests that the use of country dummies can be a potential solution in the analysis of country-specific influences on leverage, in which case each country should serve as a particular observation in the analysis, rather than using a pooled sample of all firms in all countries.

\section{Direct and indirect impact of country-specific factors}

\subsection{Hypotheses}

Several studies document that a firm's capital structure is also affected by countryspecific factors (e.g. Demirgüç-Kunt and Maksimovic, 1999; Booth, Demirgüç-Kunt and Maksimovic, 2001; Claessens, Djankov and Nenova, 2001; Bancel and Mittoo, 2004). We consider four groups of country variables. Creditor right protection (CREDITOR), bond market development (BOND) and legal enforcement (STDENFOR) tend to strengthen the role of the bond market in the economy; thus, we group these three country-specific variables as "bond market structure". Shareholder right protection (SHAREHOLDER) and the level of stock market orientation (STDMKTSTOCK) together represent the importance of the stock market in a country, and thus we refer to this group of variables as "stock market structure". In addition, we

\footnotetext{
${ }^{10}$ The finding that regression coefficients differ across countries may be driven by the fact that there are countries in our sample which have very low number of firms. Therefore, we conduct a robustness check. We take two subsamples of countries with more than 100 firms and countries with less than 100 firms and then perform the same $f$ tests within the two sub-samples. The results also reject all hypotheses.
} 
take into account the role of capital formation $(C A P I T A L)$, i.e. the level of gross domestic capital mobilization, which can have an impact on corporate financial decisions. Finally, we control for the impact of general economic conditions represented by GDP growth rate $(G D P) .^{11}$

The country characteristics may influence leverage choice through two channels. The first channel is the "direct impact", meaning that country-specific factors directly influence the debt levels of firms. We expect that corporate leverage is positively influenced by the bond market development, by which firms have more options of borrowings and creditors are more willing to provide debts (see hypothesis D1 in Table 3). Conversely, with the development of stock market where firms have more choices for and less costs of equity, we expect that firms are induced to restrict their leverage (hypothesis $D 2$ ). Finally, we hypothesize that an increase in capital formation implies more retained earnings to be accumulated, ready for further investments which are not dependent on debt usage, and as a result, the use of debt is negatively affected (hypothesis D3).

The second channel of country characteristics' impact on leverage is the "indirect impact", meaning that country-specific variables influence the way in which firm-specific factors determine firms' capital structure. The conventional theories of capital structure provide us with four sets of firm-specific determinants of leverage, namely (i) bankruptcy cost variables, (ii) tax variable, (iii) agency cost variables, and (iv) pecking order financing variables. We expect different indirect-impact relations across our three key groups of country factors and four sets of firm factors.

The roles of bankruptcy cost variables, namely tangibility, business risk and firm size, can be mitigated in a country with a more developed bond market as bankruptcy costs are better handled because of good protection for creditors. Thus, we expect a negative indirect impact of

\footnotetext{
${ }^{11}$ See Table 2 for the definitions and statistics of country-specific variables.
} 
bond market related variables on leverage via this set of firm-specific factors (hypothesis II). As for the impact of capital formation, we expect that the role of bankruptcy cost variables is mitigated because with more available internal funds, firms face less dependence on debt usage and therefore, bankruptcy costs are less of an issue (hypothesis I2).

With respect to taxation, we do not expect any significant relationship with the countryspecific variables. In each country, the effect of taxation on leverage is the outcome of a complex set of tax rules, which make leverage more or less valuable. For a country's domestically active firms only national rules apply, while international rules apply for importing and exporting firms and multinationals. Our country-level variables measure macro-economic effects, but cannot capture the subtleties of (inter)national tax effects.

Considering the agency cost variables, namely growth opportunities and tangibility, we expect that when bond and stock markets are further developed, agency problems among different stakeholders can be mitigated as the laws better protect both shareholders and creditors. Consequently, the role of agency cost variables is reduced. We, therefore, hypothesize a negative relationship between bond and stock market structure variables and the impact of growth opportunities and tangibility on leverage (hypotheses $I 3$ and I4).

Finally, country variables can have an indirect impact on pecking order financing variables, namely profitability and liquidity. We expect that capital formation has an impact of strengthening the roles of pecking order financing variables (hypothesis I5). With a higher level of available funds from capital formation, high profitability and liquidity further reduce the use of debt among domestic firms.

\subsection{Methodology}


We adopt the following methodology to analyze the direct impact of country-specific variables on leverage. In the first step, we run a simple pooled OLS regression for all firms in all countries, taking into account cross-country differences via country dummies ${ }^{12}$ :

$$
\begin{aligned}
& L E V_{i j}=\sum_{j=1}^{42} \alpha_{j} d_{j}+\sum_{j=1}^{42} \beta_{1 j} T_{A N G_{i j}}+\sum_{j=1}^{42} \beta_{2 j} R_{I S K_{i j}}+\sum_{j=1}^{42} \beta_{3 j} S I Z E_{i j}+\sum_{j=1}^{42} \beta_{4 j} T A X_{i j}+\sum_{j=1}^{42} \beta_{5 j} G R O W T H_{i j}+ \\
& +\sum_{j=1}^{42} \beta_{6 j} d_{j} \text { PROFIT }_{i j}+\sum_{j=1}^{42} \beta_{7 j} d_{j} \text { LIQUID }_{i j}+u_{i j}
\end{aligned}
$$

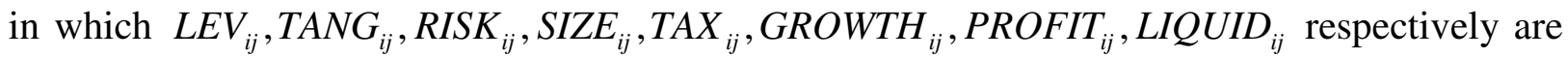
the leverage and firm-specific characteristics of firm $i$ in country $j ; d_{j}$ are the country dummies. In the second step, we explore the role of country-specific variables in explaining the estimators of country dummy coefficients $\alpha_{j}$ (which are the countries' leverages after correcting for impacts of firm-specific determinants) by using the following Weighted Least Squares (WLS) regression:

$$
\begin{aligned}
& \hat{\alpha}_{j}=\gamma_{0}+\gamma_{1} \text { STDENFOR }_{j}+\gamma_{2} \text { CREDITOR }_{j}+\gamma_{3} \text { BOND }_{j}+\gamma_{4} \text { STDMKTSTOCK }_{j}+ \\
& +\gamma_{5} \text { SHAREHOLDER }_{j}+\gamma_{6} \text { CAPITAL }_{j}+\gamma_{7} \text { GDP }_{j}+w_{j}
\end{aligned}
$$

in which $S T D E N F O R_{j}, C_{\text {REDITOR }}$, BOND $_{j}$, STDMKTSTOCK $_{j}$, SHAREHOLDER $_{j}, C_{A P I T A L}$, and $G D P_{j}$ are country characteristics defined in Table 2. The observations for the dependent variable are the estimators of $\alpha_{j}$ in Equation (2). Equation (3) explains estimated country dummy coefficients against a set of country-specific variables explicitly allowing for the fact that the estimated coefficients of firm-specific determinants are different across countries. The weights used in Equation (3) are inverse standard errors of the corresponding country dummies. These weights allow us to take into account the statistical significance of related variables. ${ }^{13}$

\footnotetext{
${ }^{12}$ By construction, this regression yields the same coefficients as provided by Equation (1) in which the estimates of country dummies are equal to the intercepts.

${ }^{13}$ We thank an anonymous referee for suggesting this methodology.
} 
Having established the direct impact of country-specific variables on corporate leverage, we proceed to examine the indirect impact of country-specific variables by estimating the effect on firm-specific determinants. In order to do this, we first estimate the regression coefficients of all firm-specific variables TANG, RISK, SIZE, TAX, GROWTH, PROFIT, and LIQUID $\left(\hat{\beta}_{1 j}, \hat{\beta}_{2 j}, \hat{\beta}_{3 j}, \hat{\beta}_{4 j}, \hat{\beta}_{5 j}, \hat{\beta}_{6 j}\right.$, and $\hat{\beta}_{7 j}$, respectively) from Equation (1) for each country. We then regress the values of coefficients on the country-specific variables, again using the WLS estimation as mentioned earlier. The regression specification is written as follows:

$$
\begin{aligned}
& \hat{\beta}_{k j}=\lambda_{0}+\lambda_{1} \text { STDENFOR }_{j}+\lambda_{2} \text { CREDITOR }_{j}+\lambda_{3} \text { BOND }_{j}+\lambda_{4} \text { STDMKTSTOCK }_{j}+ \\
& +\lambda_{5} \text { SHAREHOLDER }_{j}+\lambda_{6} \text { CAPITAL }_{j}+\lambda_{7} \text { GDP }_{j}+e_{k}
\end{aligned}
$$

in which $k$ denotes the coefficients of firm-specific factors estimated in Equation (1) and $j$ denotes a country. We also test various reduced forms of this equation. ${ }^{14}$

\subsection{Results: direct impact of country-specific factors}

The results examining the direct impact of country-specific variables on leverage are presented in Table 6. The estimated regression coefficients of explanatory variables are shown in different columns. We observe that notwithstanding the limited number of countries in the sample, the adjusted- $\mathrm{R}^{2}$ of all regressions is above $50 \%$. It indicates that the model specification we use captures a good part of the variations in country dummy coefficients. Country-specific determinants, therefore, should not be neglected in capital structure studies since they have a sizeable explanatory power.

[Insert Table 6 about here]

\footnotetext{
${ }^{14}$ The analyses of both direct and indirect impacts of country-specific variables are the second stages of a two-stage procedure. As we estimate the regressions in independent runs, we implicitly assume that the residuals of the regressions in the first stage are not correlated with the country-specific variables.
} 
The regression results show that corporate leverage is directly related to a number of country-specific factors. Factors like creditor right protection, bond market development and GDP growth rate consistently show statistically significant impact on capital structure. We find that the level of bond market development has a positive impact on capital structure, which is consistent with hypothesis D1. When a country's bond market is further developed, firms have more choice for borrowing and are willing to take in more debt. Next, creditor right protection has a significantly negative impact on the leverage level of corporate sector, which does not support hypothesis D1. A possible explanation for this effect is that higher creditor right protection implies that debt is more risky for firms in general since firms are likely to be forced into bankruptcy in times of financial distress. Firms, therefore, are more reluctant to borrow as they become concerned with relatively stringent debt contracts that the creditors may impose on them.

We do not find any significant support for hypotheses D2 and D3. Finally, as we control for the general economic conditions of the countries, GDP growth rate variable yields a positive impact and the coefficients are significant at $1 \%$ level across all model specifications. The finding indicates that in countries with relatively higher rate of economic growth, firms are more willing to use higher levels of debt to finance new investments.

\subsection{Results: indirect impact of country-specific factors}

The novel argument in this study is that country-characteristics have the potential to influence the importance of firm-specific determinants of corporate leverage. Therefore, we now examine to what extent institutional differences across countries affect the impact of firmspecific factors. As discussed earlier, the estimated coefficient of each of the firm-specific 
determinants for each country (Equation 1) is used as the dependent variable. The results on the indirect impact of country factors (Equation 4) are presented in Table 7. The regression coefficients of country-specific factors used as explanatory variables are presented in various columns. As robustness checks, we also run many other regressions with different combinations of explanatory variables; none of the results are found to be conflicting (therefore not reported here). ${ }^{15}$

[Insert Table 7 about here]

The overall results support the claim that country-specific factors also have an impact on the roles of firm-specific determinants of capital structure. We find a significantly negative effect of the variable representing market/bank-based financial system and stock market development (STDMKTSTOCK) on the estimated coefficient of asset tangibility, supporting a part of hypothesis I4. A developed stock market, for example, tends to mitigate the use of debt as it instead promotes the use of equity. As a result, the role of tangibility as collateral in borrowing is limited. We also find a strong evidence for hypothesis $I 5$ as all the coefficients of CAPITAL are significantly negative for the case of profitability and liquidity. The negative impact of these two firm-specific variables on leverage is further strengthened when more domestic capital funds are accumulated.

We also observe that a country' legal system of enforcement indirectly influences capital structure in several ways. Firstly, a negative impact on firm size coefficients indicates that firm size is relatively less important for leverage choice of firms. As firm size is a reverse proxy of bankruptcy cost/risk, better law enforcement is likely to force borrowers to abide by their debt

\footnotetext{
${ }^{15} \mathrm{We}$ do not report the regressions for TAX because no specification yields a statistically significant coefficient.
} 
contracts. The result is consistent with our hypothesis $I 1$. On the other hand, in countries with lower enforcement, the role of firm size as a proxy for information asymmetry alleviation is further enhanced. Secondly, firms operating in an environment with effective enforcement have to consider more carefully about their leverage choice because bankruptcy risk becomes more important. Higher law enforcement also makes the impact of profitability more important. According to the free cash flow theory, debt is used as a bonding or disciplinary device to ensure that the management pays out profits, rather than engages in empire-building activities (Jensen, 1986). Better law enforcement, including reduced level of corruption, further strengthens the role of profitability in making debt more aligned with its disciplinary role.

Although we do not find any evidence for hypotheses $I 2$ and $I 3$, we do observe several significant relationships which are not hypothesized but can be explained. Shareholder right protection has a significant positive effect on firm size coefficient and a significant negative effect on profitability coefficient. Firm size can be a proxy for information asymmetry: larger firms are expected to have less information asymmetry. When shareholders are better protected, firms are more likely to be operated in alignment with shareholders' interest, thereby strengthening the influence of firm size. On the other hand, shareholder right protection strengthens the negative impact of profitability on leverage, as firms have to care more about their performance to fit with shareholders' interests. The control variable, GDP, shows up with a significantly strengthening impact on the role of growth opportunities.

Taken as a whole, the results presented in Tables 6 and 7 suggest significant roles of various country-specific factors, not only directly determining corporate leverage, but also affecting the way firm-specific factors influence firms' choice of capital structure. We find that legal enforcement-related factors and variables characterizing the economic development of countries tend to show the greatest impacts, both directly and indirectly. 


\section{Conclusions}

Capital structure theories have been mostly developed and tested in the single-country context. Researchers have identified several firm-specific determinants of a firm's leverage, based on the three most accepted theoretical models of capital structure, i.e. the static trade-off theory, the agency theory and the pecking-order theory. A large number of studies have been conducted to date investigating to what extent these factors influence capital structures of firms operating within a specific country. In this paper, we examine the role of firm-specific determinants of corporate leverage choice around the world. We analyze a large sample of 42 countries, divided equally between developed and developing countries. Our main objective is to verify the role of various country-specific factors in determining corporate capital structure. We distinguish two types of effects: the direct effect on leverage and the indirect effect through the influence on firm-specific determinants of corporate leverage.

We find that the impact of several firm-specific factors like tangibility, firm size, risk, growth and profitability on cross-country capital structure is significant and consistent with the prediction of conventional capital structure theories. On the other hand, we also observe that in each country one or more firm-specific factors are not significantly related to leverage. For some countries, we find results that are inconsistent with theoretical predictions.

Several studies analyzing international capital structure assume cross-country equality of firm-level determinants. We show that this assumption is unfounded. Rather, it is necessary to conduct an analysis of country-specific factors by including countries as observations and avoid a specification using a pooled regression method. We conduct regressions using country-specific factors to explain coefficients of country dummies as well as firm-specific determinants. 
Analyzing the direct impact of country-specific factors on leverage, the evidence suggests that creditor right protection, bond market development, and GDP growth rate have a significant influence on corporate capital structure. In measuring the impact indirectly, we find evidence for the importance of legal enforcement, creditor/shareholder right protection, and macro-economic measures such as capital formation and GDP growth rate. It implies that in countries with a better legal environment and more stable and healthier economic conditions, firms are not only likely to take more debt, but the effects of firm-level determinants of leverage are also reinforced. Overall, the evidence provided here highlights the importance of countryspecific factors in corporate capital structure decisions. Our conclusion is that country-specific factors do matter in determining and affecting the leverage choice around the world, and it is useful to take into account these factors in the analysis of a country's capital structure. If the limitations of data, especially the number of countries, can be overcome, one might find even more significant results with respect to the impact of country-specific factors. 


\section{References}

Bancel, F., and Mittoo, U., 2004. Cross-country determinants of capital structure choice: a survey of European firms. Financial Management 33: 4, Winter, 103-132.

Beck, T., Demirgüç-Kunt, A., and Maksimovic, V., 2002. Financing patterns around the world: the role of institutions. World Bank Policy Research Working Paper 2905.

Bekaert, G. and Harvey, C., 2003. Emerging markets finance. Journal of Empirical Finance 10, $3-55$.

Berkowitz, D., Pistor, K. and Richard, J-F., 2003. Economic development, legality, and the transplant effect. European Economic Review 47, 165-195.

Booth, L., Aivazian, V., Demirgüç-Kunt, A., and Maksimovic, V., 2001. Capital structure in developing countries. Journal of Finance 56, 87-130.

Brounen, D., De Jong, A., and Koedijk, K., 2006. Capital structure policies in Europe: survey evidence. Journal of Banking and Finance 30, 1409-1442.

Claessens, S., and Klapper, L., 2002. Bankruptcy around the world: explanations of its relative use. World Bank Policy Research Working Paper 2865.

Claessens, S., Djankov, S., and Lang, L., 2000. The separation of ownership and control in East Asian corporations. Journal of Financial Economics 58, 81-112.

Claessens, S., Djankov, S., and Nenova, T., 2001. Corporate risk around the world, in: Glick, R., Monerno, R. and Spiegel, M. (Eds.), Financial crises in emerging markets, Cambridge University Press, 305-338. 
Deesomsak, R., Paudyal, K., and Pescetto, G., 2004. The determinants of capital structure: evidence from the Asia Pacific region. Journal of Multinational Financial Management $14,387-405$.

Demirgüç-Kunt, A. and Levine, R., 2001. Bank-based and market-based financial systems: cross-country comparisons, in: Demirgüç-Kunt, A. and Levine, R. (Eds.), Financial structure and economic growth: a cross-country comparison of banks, markets, and development, MIT Press, Cambridge, MA., pp. 81-140.

Demirgüç-Kunt, A. and Maksimovic, V., 1999. Institutions, financial markets and firm debt maturity. Journal of Financial Economics 54, 295-336.

Fan, J., Titman, S. and Twite, G., 2006. An international comparison of capital structure and debt maturity choices. Working Paper, www.ssrn.com

Giannetti, M., 2003. Do better institutions mitigate agency problems? Evidence from corporate finance choices. Journal of Financial and Quantitative Analysis 38, 185-212.

Graham, J. and Harvey, C. (2001), "The theory and practice of corporate finance: Evidence from the field", Journal of Financial Economics 60, 187-243.

Hall, G., Hutchinson, P and Michaelas, N., 2004. Determinants of the capital structures of European SMEs. Journal of Business Finance and Accounting 31, 711-728.

Hovakimian, A., Opler, T. and Titman, S., 2001. The debt-equity choice. Journal of Financial and Quantitative Analysis 36, 1-24.

Jensen, M., 1986. Agency costs of free cash flow, corporate finance and takeovers. American Economic Review 76, 323-339. 
Jensen, M. and Meckling, W., 1976. Theory of the firm: managerial behavior, agency costs and ownership structure. Journal of Financial Economics 3, 305-360.

La Porta, R., Lopez-De-Silanes, F, Shleifer, A. and Vishny, R., 1998. Law and finance. Journal of Political Economy 106, 1113-1155.

Levine, R., 2002. Bank-based or market-based financial systems: which is better? Journal of Financial Intermediation 11, 398-428.

MacKie-Mason, J., 1990. Do taxes effect corporate financing decisions? Journal of Finance 45, 1471-1495.

Rajan, R. and Zingales, L., 1995. What do we know about capital structure? Some evidence from international data. Journal of Finance 50, 1421-1460.

Shyam-Sunder, L., and Myers, S., 1999. Testing static tradeoff against pecking order models of capital structure. Journal of Financial Economics 51, 219-244.

Song, J. and Philippatos, G., 2004. Have we resolved some critical issues related to international capital structure? Empirical evidence from the 30 OECD countries. Working Paper, University of Tennessee.

Titman, S., and Wessels, R., 1988. The determinants of capital structure. Journal of Finance 43, 1-19.

Verbeek, M., 2004. A guide to modern econometrics. John Wiley \& Sons, England.

Wald, J., 1999. How firm characteristics affect capital structure: an international comparison. Journal of Financial Research 22, 161-187. 


\section{Table 1: Cross-country statistics of leverage and other firm-specific variables}

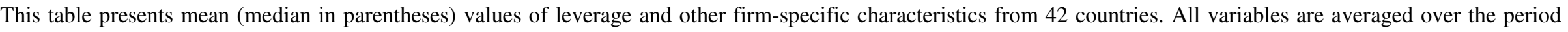

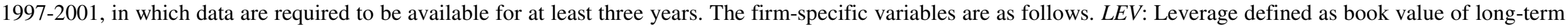

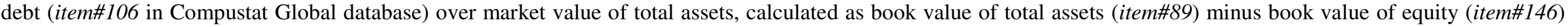

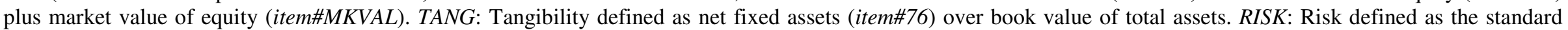

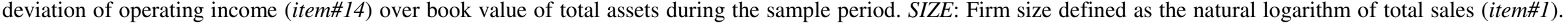

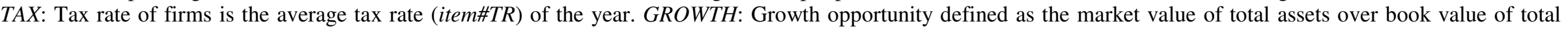

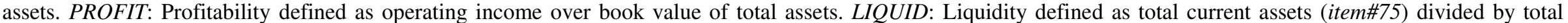
current liabilities (item\#104). Obs. is the number of firms per country.

\begin{tabular}{|c|c|c|c|c|c|c|c|c|c|}
\hline Country & $L E V$ & $T A N G$ & RISK & $S I Z E$ & $T A X$ & GROWTH & PROFIT & LIQUID & Obs. \\
\hline \multirow[t]{2}{*}{ Argentina } & 0.229 & 0.600 & 0.030 & 5.99 & 15.96 & 2.308 & 0.105 & 1.749 & 23 \\
\hline & $(0.236)$ & $(0.567)$ & $(0.030)$ & (6.11) & (15.61) & $(0.900)$ & $(0.095)$ & $(0.905)$ & \\
\hline \multirow[t]{2}{*}{ Australia } & 0.116 & 0.338 & 0.113 & 4.85 & 21.99 & 1.936 & 0.035 & 2.718 & 254 \\
\hline & $(0.081)$ & $(0.296)$ & $(0.063)$ & $(5.05)$ & (27.37) & $(1.362)$ & $(0.069)$ & $(1.463)$ & \\
\hline \multirow[t]{2}{*}{ Austria } & 0.103 & 0.327 & 0.037 & 5.04 & 17.78 & 1.418 & 0.076 & 3.198 & 60 \\
\hline & $(0.081)$ & $(0.361)$ & $(0.023)$ & $(5.14)$ & (23.02) & (1.133) & $(0.086)$ & $(1.556)$ & \\
\hline \multirow[t]{2}{*}{ Belgium } & 0.112 & 0.291 & 0.039 & 5.32 & 31.80 & 1.908 & 0.119 & 1.688 & 82 \\
\hline & $(0.088)$ & $(0.278)$ & $(0.023)$ & $(5.17)$ & $(27.06)$ & (1.344) & $(0.121)$ & $(1.363)$ & \\
\hline Brazil & $(0.136)$ & $(0.517)$ & $(0.039)$ & (6.72) & (24.34) & $(0.856)$ & $(0.121)$ & (1.179) & \\
\hline \multirow[t]{2}{*}{ Canada } & 0.150 & 0.447 & 0.082 & 5.32 & 23.41 & 2.029 & 0.071 & 3.036 & 413 \\
\hline & $(0.128)$ & $(0.425)$ & $(0.048)$ & $(5.57)$ & $(28.02)$ & (1.419) & $(0.114)$ & $(1.792)$ & \\
\hline \multirow[t]{2}{*}{ Chile } & 0.187 & 0.572 & 0.034 & 4.31 & 10.50 & 1.032 & 0.107 & 2.500 & 81 \\
\hline & $(0.134)$ & $(0.598)$ & $(0.025)$ & $(4.35)$ & (11.70) & $(0.954)$ & $(0.101)$ & $(1.543)$ & \\
\hline \multirow[t]{2}{*}{ China } & 0.17 & 0.435 & 0.038 & 7.26 & 11.83 & 1.019 & 0.071 & 1.848 & 108 \\
\hline & $(0.047)$ & $(0.370)$ & $(0.028)$ & (7.28) & (13.74) & $(0.823)$ & $(0.066)$ & $(1.408)$ & \\
\hline Colombia & 0.112 & 0.501 & 0.025 & 5.79 & 14.96 & 0.764 & 0.062 & 1.635 & 14 \\
\hline \multirow[t]{2}{*}{ Croatia } & 0.128 & 0.617 & 0.022 & 2.37 & 29.88 & 1.001 & 0.133 & 1.703 & 13 \\
\hline & $(0.086)$ & $(0.632)$ & $(0.014)$ & (2.08) & $(30.32)$ & $(0.914)$ & $(0.113)$ & (1.166) & \\
\hline \multirow[t]{2}{*}{ Denmark } & 0.134 & 0.356 & 0.055 & 6.87 & 27.48 & 1.685 & 0.098 & 2.061 & 99 \\
\hline & $(0.104)$ & $(0.336)$ & $(0.030)$ & (6.81) & (28.87) & (1.107) & $(0.113)$ & $(1.586)$ & \\
\hline \multirow[t]{2}{*}{ Finland } & 0.121 & 0.315 & 0.061 & 5.08 & 30.95 & 2.271 & 0.132 & 2.147 & 97 \\
\hline & $(0.107)$ & $(0.272)$ & $(0.040)$ & $(4.70)$ & $(29.20)$ & (1.372) & $(0.135)$ & (1.739) & \\
\hline \multirow[t]{2}{*}{ France } & 0.097 & 0.184 & 0.053 & 4.92 & 26.07 & 2.034 & 0.111 & 1.880 & 504 \\
\hline & $(0.073)$ & $(0.143)$ & $(0.031)$ & $(4.58)$ & (33.68) & (1.382) & $(0.110)$ & $(1.492)$ & \\
\hline
\end{tabular}


Table 1 (continued): Cross-country statistics of leverage and other firm-specific variables

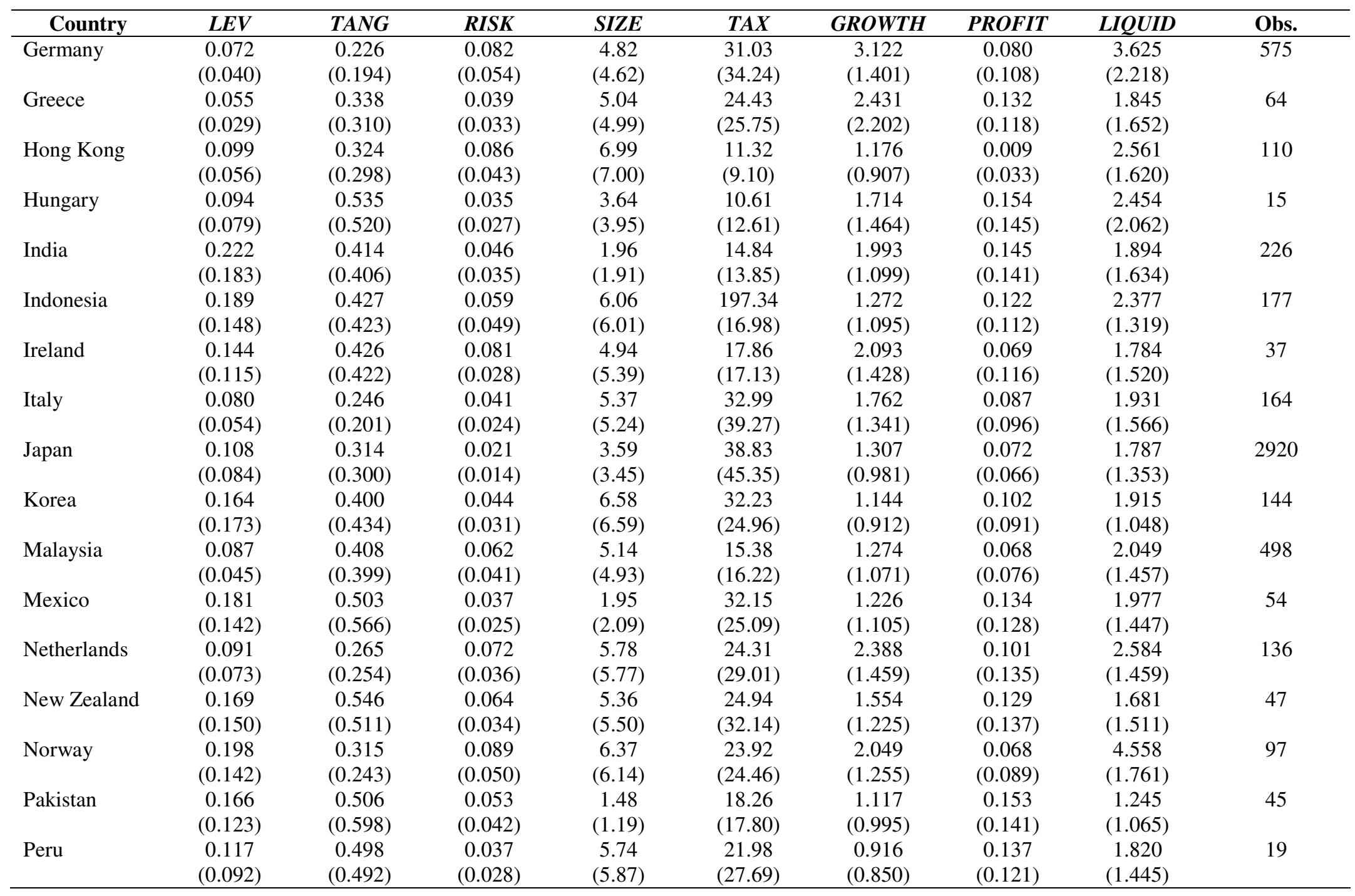


Table 1 (continued): Cross-country statistics of leverage and other firm-specific variables

\begin{tabular}{|c|c|c|c|c|c|c|c|c|c|}
\hline Country & $L E V$ & $T A N G$ & RISK & SIZE & $T A X$ & GROWTH & PROFIT & LIQUID & Obs. \\
\hline \multirow[t]{2}{*}{ Philippines } & 0.136 & 0.476 & 0.088 & 0.25 & 21.14 & 6.551 & 0.086 & 5.491 & 77 \\
\hline & $(0.074)$ & $(0.466)$ & $(0.041)$ & $(0.40)$ & (12.73) & $(0.886)$ & $(0.065)$ & $(1.249)$ & \\
\hline Poland & 0.052 & 0.403 & 0.054 & 6.53 & 31.84 & 1.401 & 0.124 & 2.075 & 23 \\
\hline \multirow[t]{2}{*}{ Portugal } & 0.135 & 0.407 & 0.030 & 5.82 & 29.69 & 1.565 & 0.100 & 1.079 & 31 \\
\hline & $(0.116)$ & $(0.417)$ & $(0.026)$ & (6.03) & $(26.69)$ & (1.167) & $(0.093)$ & $(1.085)$ & \\
\hline \multirow[t]{2}{*}{ Singapore } & 0.093 & 0.354 & 0.060 & 4.56 & 19.04 & 1.326 & 0.074 & 1.897 & 310 \\
\hline & $(0.056)$ & $(0.346)$ & $(0.042)$ & $(4.46)$ & $(20.48)$ & (1.115) & $(0.073)$ & $(1.536)$ & \\
\hline \multirow[t]{2}{*}{ Spain } & 0.103 & 0.383 & 0.028 & 5.99 & 22.87 & 1.809 & 0.120 & 1.423 & 93 \\
\hline & $(0.078)$ & $(0.379)$ & $(0.022)$ & (5.92) & $(25.39)$ & $(1.362)$ & $(0.111)$ & $(1.223)$ & \\
\hline \multirow[t]{2}{*}{ Sweden } & 0.103 & 0.216 & 0.101 & 6.30 & 21.57 & 2.244 & 0.017 & 3.081 & 206 \\
\hline & $(0.057)$ & $(0.163)$ & $(0.057)$ & (6.49) & $(24.17)$ & (1.608) & $(0.091)$ & $(2.180)$ & \\
\hline \multirow[t]{2}{*}{ Switzerland } & 0.148 & 0.367 & 0.050 & 5.98 & 20.30 & 1.875 & 0.096 & 2.290 & 164 \\
\hline & $(0.114)$ & $(0.340)$ & $(0.024)$ & $(5.90)$ & $(22.14)$ & $(1.275)$ & (0.114) & $(1.821)$ & \\
\hline \multirow{2}{*}{ Taiwan } & 0.113 & 0.370 & 0.029 & 2.39 & 6.70 & 1.605 & 0.076 & 1.690 & 153 \\
\hline & $(0.092)$ & $(0.370)$ & $(0.022)$ & $(2.41)$ & (8.05) & (1.330) & $(0.065)$ & $(1.461)$ & \\
\hline Thailand & 0.174 & 0.452 & 0.053 & 7.52 & 10.41 & 0.994 & 0.094 & 1.665 & 244 \\
\hline \multirow[t]{2}{*}{ Turkey } & 0.059 & 0.324 & 0.081 & 4.55 & 30.05 & 2.648 & 0.221 & 1.799 & 39 \\
\hline & $(0.031)$ & $(0.313)$ & $(0.061)$ & $(4.57)$ & (27.03) & (1.967) & $(0.232)$ & $(1.579)$ & \\
\hline \multirow[t]{2}{*}{ UK } & 0.084 & 0.333 & 0.082 & 4.71 & 21.20 & 2.212 & 0.092 & 2.259 & 795 \\
\hline & $(0.056)$ & $(0.280)$ & $(0.048)$ & (4.64) & $(25.52)$ & (1.564) & $(0.119)$ & $(1.426)$ & \\
\hline \multirow[t]{2}{*}{ US } & 0.144 & 0.295 & 0.084 & 5.86 & 24.90 & 2.667 & 0.074 & 2.982 & 2537 \\
\hline & $(0.093)$ & $(0.232)$ & $(0.046)$ & (5.94) & $(32.42)$ & (1.760) & $(0.116)$ & $(2.061)$ & \\
\hline
\end{tabular}




\section{Table 2: Description and summary statistics of country-specific variables}

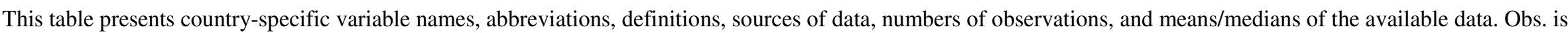
the number of countries with available data and information.

\begin{tabular}{|c|c|c|c|c|}
\hline \multirow[t]{2}{*}{ Name (abbreviation) } & \multirow[t]{2}{*}{ Description } & \multicolumn{3}{|c|}{ Statistics } \\
\hline & & Mean & Median & Obs. \\
\hline $\begin{array}{l}\text { Efficiency of judicial } \\
\quad \text { system }(J U D I C I A L)\end{array}$ & $\begin{array}{l}\text { The assessment of the "efficiency and integrity of the legal environment as it affects business, } \\
\text { particularly foreign firms", as defined by La Porta et al. (1998), averaged through 1980-1983. }\end{array}$ & 7.836 & 8.375 & 38 \\
\hline Rule of law (RULE) & $\begin{array}{l}\text { The assessment of the law and order tradition in the country, defined by La Porta et al. (1998), } \\
\text { averaged through 1982-1995. }\end{array}$ & 7.584 & 8.545 & 40 \\
\hline Legality ( $L E G A L)$ & $\begin{array}{l}\text { The index derived from a principal component analysis of the five observed legality variables, defined } \\
\text { by Berkowitz et al. (2003), period: } 1980-1995 \text {. }\end{array}$ & 17.074 & 18.270 & 38 \\
\hline Corruption (CORRUP) & $\begin{array}{l}\text { International Country Risk assessment of the corruption in governments as defined by La Porta } \text { et al. } \\
\text { (1998), average through 1982-1995. }\end{array}$ & 7.321 & 7.800 & 38 \\
\hline $\begin{array}{l}\text { Standardized enforcement } \\
\quad(\text { STDENFOR })\end{array}$ & $\begin{array}{l}\text { The average of standardized values of JUDICIAL, RULE, LEGAL, and CORRUP. In case of missing } \\
\text { values, we take the average of available data. }\end{array}$ & 0.000 & 0.077 & 40 \\
\hline $\begin{array}{l}\text { Creditor right protection } \\
\quad(C R E D I T O R)\end{array}$ & $\begin{array}{l}\text { Creditor right protection, an index aggregating different creditor rights as defined by La Porta et al., } \\
\text { 1998. (Source: La Porta et al. 1998, and Claessens and Klapper, 2002). }\end{array}$ & 2.050 & 2.000 & 40 \\
\hline $\begin{array}{l}\text { Bond market development } \\
\qquad(B O N D)\end{array}$ & $\begin{array}{l}\text { The development of bond market defined as the total (private plus public) bond market capitalization } \\
\text { over GDP, average through 1997-2001 (source: World Bank, Financial Structure Database). Data } \\
\text { for Indonesia are averaged through 1990-1994 (source: World Bank, The emerging Asian bond } \\
\text { market, June 1995). }\end{array}$ & 0.577 & 0.496 & 40 \\
\hline $\begin{array}{l}\text { Market/Bank-based } \\
\text { financial system } \\
(M K T B A S E)\end{array}$ & $\begin{array}{l}\text { A dummy variable that equals } 1 \text { if the country's financial system is market-based and } 0 \text { if it is bank- } \\
\text { based. (Sources: Demirgüç-Kunt and Levine, 2001; for China, Taiwan and Croatia: the National } \\
\text { Bank and Statistics Office of the corresponding country). }\end{array}$ & 0.568 & 1.000 & 42 \\
\hline $\begin{array}{l}\text { Stock market development } \\
\qquad(S T O C K)\end{array}$ & $\begin{array}{l}\text { The development of stock market in a country is defined as the stock market capitalization over the } \\
\text { country's GDP, average through 1997-2001. (Source: World Development Indicators and Financial } \\
\text { Structure Database). }\end{array}$ & 0.640 & 0.440 & 42 \\
\hline $\begin{array}{l}\text { Standardized stock market } \\
\quad(\text { STDMKTSTOCK) }\end{array}$ & The average of standardized MKTBASE and standardized STOCK & 0.000 & 0.017 & 42 \\
\hline $\begin{array}{l}\text { Shareholder right } \\
\text { protection } \\
(\text { SHAREHOLDER })\end{array}$ & $\begin{array}{l}\text { Shareholder right protection, an index aggregating different shareholder rights as defined by La Porta } \\
\text { et al. (1998). (Source: La Porta et al. 1998). }\end{array}$ & 3.132 & 3.000 & 38 \\
\hline $\begin{array}{l}\text { Capital formation } \\
\text { (CAPITAL) }\end{array}$ & $\begin{array}{l}\text { Defined as the average of annual gross capital formation (as a proportion of GDP) in each country, } \\
\text { averaged through 1997-2001. (Source: World Development Indicators). }\end{array}$ & 0.228 & 0.222 & 42 \\
\hline GDP growth $(G D P)$ & $\begin{array}{l}\text { Defined as the average of annual real GDP growth rate (unit: \%) of each country, averaged through } \\
\text { 1997-2001. (Source: World Development Indicators). }\end{array}$ & 3.122 & 2.972 & 42 \\
\hline
\end{tabular}




\section{Table 3: Hypotheses}

The table summarizes the hypotheses for the firm- and country-specific effects, and the hypotheses for equal firm-specific coefficient tests.

\section{Firm-specific effects}

Hypothesis F1:

Hypothesis F2:

Hypothesis F3:

Hypothesis F4:

Hypothesis F5:

Hypothesis F6:

Hypothesis F7:
Tangibility has a positive effect on leverage

Business risk has a negative effect on leverage

Firm size has a positive effect on leverage

Tax has a positive effect on leverage

Growth opportunities have a negative effect on leverage

Profitability has a negative effect on leverage

Liquidity has a negative effect on leverage

Equal firm-specific coefficients

Hypothesis EC1: Tangibility coefficients are equal across all countries

Hypothesis EC2: $\quad$ Risk coefficients are equal across all countries

Hypothesis EC3: $\quad$ Size coefficients are equal across all countries

Hypothesis EC4: $\quad$ Tax coefficients are equal across all countries

Hypothesis EC5: $\quad$ Growth opportunity coefficients are equal across all countries

Hypothesis EC6: Profitability coefficients are equal across all countries

Hypothesis EC7: Liquidity coefficients are equal across all countries

Hypothesis EC8: All firm-specific variables' coefficients are simultaneously equal across all countries

Direct country-specific effects

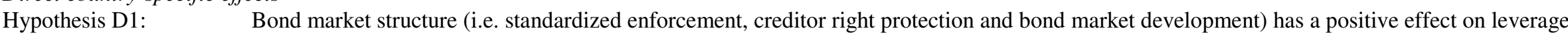

Hypothesis D2: $\quad$ Stock market structure (i.e. standardized stock market and shareholder right protection) has a negative effect on leverage

Hypothesis D3: $\quad$ Capital formation has a negative effect on leverage

Indirect country-specific effects

Hypothesis I1:

Hypothesis I2:

Hypothesis I3:

Hypothesis I4:

Bond market structure mitigates the effect of bankruptcy costs (tangibility, risk and size) on leverage

Hypothesis I5:

Capital formation mitigates the effect of bankruptcy costs (tangibility, risk and size) on leverage

Bond market structure mitigates the effect of agency costs (growth opportunities and tangibility) on leverage

Stock market structure mitigates the effect of agency costs (growth opportunities and tangibility) on leverage

Capital formation strengthens the effect of pecking order financing (profitability and liquidity) on leverage 


\section{Table 4: Impact of firm-specific variables on leverage across countries}

This table presents regression results of leverage on firm-specific variables for 42 countries using annual average data of 1997 - 2001 estimated from Equation (1):

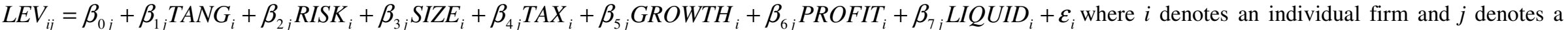

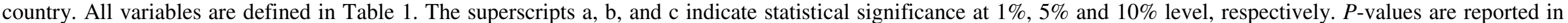

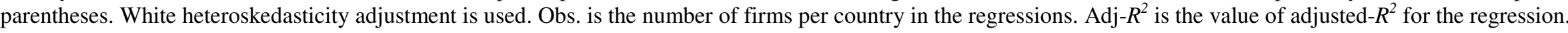

\begin{tabular}{|c|c|c|c|c|c|c|c|c|c|c|}
\hline Country & Intercept & TANG & RISK & SIZE & $T A X$ & GROWTH & PROFIT & LIQUID & Obs. & $\operatorname{Adj}-R^{2}$ \\
\hline \multirow[t]{2}{*}{$\overline{\text { Argentina }}$} & -0.151 & $0.620^{a}$ & 1.976 & 0.012 & $-0.003^{b}$ & 0.003 & -0.400 & $-0.020^{c}$ & 23 & 0.55 \\
\hline & $(0.441)$ & $(0.000)$ & $(0.298)$ & $(0.698)$ & $(0.021)$ & $(0.140)$ & $(0.582)$ & $(0.078)$ & & \\
\hline \multirow[t]{2}{*}{ Australia } & 0.030 & $0.161^{a}$ & $-0.161^{b}$ & $0.016^{a}$ & 0.000 & $-0.007^{b}$ & $-0.160^{a}$ & -0.001 & 254 & 0.23 \\
\hline & $(0.258)$ & $(0.000)$ & $(0.026)$ & $(0.000)$ & $(0.903)$ & $(0.034)$ & $(0.000)$ & $(0.231)$ & & \\
\hline \multirow[t]{2}{*}{ Austria } & -0.010 & $0.201^{b}$ & 0.464 & 0.011 & 0.000 & -0.017 & -0.019 & 0.001 & 60 & 0.23 \\
\hline & $(0.886)$ & $(0.011)$ & $(0.419)$ & $(0.239)$ & $(0.180)$ & $(0.192)$ & $(0.878)$ & $(0.361)$ & & \\
\hline \multirow[t]{2}{*}{ Belgium } & $0.097^{b}$ & $0.226^{\mathrm{a}}$ & -0.086 & -0.001 & 0.000 & $-0.015^{a}$ & -0.097 & -0.007 & 82 & 0.30 \\
\hline & $(0.070)$ & $(0.000)$ & $(0.408)$ & $(0.917)$ & $(0.352)$ & $(0.005)$ & $(0.176)$ & $(0.378)$ & & \\
\hline \multirow[t]{2}{*}{ Brazil } & $0.192^{c}$ & $0.139^{c}$ & 0.034 & -0.005 & 0.000 & 0.014 & $-0.423^{c}$ & -0.020 & 101 & 0.04 \\
\hline & $(0.093)$ & $(0.080)$ & $(0.942)$ & $(0.691)$ & $(0.372)$ & $(0.362)$ & $(0.069)$ & $(0.442)$ & & \\
\hline \multirow[t]{2}{*}{ Canada } & 0.024 & $0.184^{a}$ & $-0.194^{a}$ & $0.021^{a}$ & 0.000 & $-0.014^{a}$ & $-0.259^{a}$ & -0.001 & 413 & 0.36 \\
\hline & $(0.372)$ & $(0.000)$ & $(0.003)$ & $(0.000)$ & $(0.745)$ & $(0.003)$ & $(0.000)$ & $(0.132)$ & & \\
\hline \multirow[t]{2}{*}{ Chile } & 0.075 & $0.243^{a}$ & -0.851 & $0.034^{a}$ & 0.000 & $-0.145^{a}$ & 0.037 & -0.002 & 81 & 0.37 \\
\hline & $(0.373)$ & $(0.010)$ & $(0.237)$ & $(0.002)$ & $(0.910)$ & $(0.000)$ & $(0.909)$ & $(0.695)$ & & \\
\hline \multirow[t]{2}{*}{ China } & $-0.321^{a}$ & $0.414^{a}$ & -0.289 & $0.041^{a}$ & 0.000 & -0.014 & $-0.421^{c}$ & 0.008 & 108 & 0.44 \\
\hline & $(0.001)$ & $(0.000)$ & $(0.264)$ & $(0.000)$ & $(0.646)$ & $(0.353)$ & $(0.077)$ & $(0.178)$ & & \\
\hline \multirow[t]{2}{*}{ Colombia } & -0.068 & 0.095 & 0.174 & 0.006 & -0.004 & 0.172 & -0.097 & 0.016 & 14 & 0.001 \\
\hline & $(0.882)$ & $(0.482)$ & $(0.922)$ & (0.799) & $(0.319)$ & $(0.408)$ & $(0.895)$ & $(0.834)$ & & \\
\hline \multirow[t]{2}{*}{ Croatia } & 0.459 & -0.101 & 2.673 & 0.089 & $-0.011^{c}$ & -0.128 & -0.390 & -0.014 & 13 & 0.48 \\
\hline & $(0.230)$ & $(0.804)$ & $(0.397)$ & $(0.112)$ & $(0.070)$ & $(0.234)$ & $(0.563)$ & $(0.765)$ & & \\
\hline \multirow[t]{2}{*}{ Denmark } & 0.015 & $0.297^{a}$ & 0.004 & 0.008 & 0.000 & $-0.017^{a}$ & -0.102 & 0.000 & 99 & 0.27 \\
\hline & $(0.823)$ & $(0.000)$ & $(0.987)$ & $(0.269)$ & $(0.256)$ & $(0.002)$ & $(0.289)$ & $(0.996)$ & & \\
\hline \multirow[t]{2}{*}{ Finland } & $0.103^{b}$ & $0.249^{a}$ & $-0.264^{c}$ & 0.003 & -0.001 & -0.003 & $-0.164^{b}$ & -0.006 & 97 & 0.39 \\
\hline & $(0.060)$ & $(0.000)$ & $(0.053)$ & $(0.536)$ & $(0.138)$ & $(0.204)$ & $(0.044)$ & $(0.429)$ & & \\
\hline \multirow[t]{2}{*}{ France } & $0.065^{a}$ & $0.275^{a}$ & -0.034 & $0.004^{c}$ & 0.000 & $-0.009^{a}$ & $-0.075^{b}$ & $-0.004^{b}$ & 503 & 0.32 \\
\hline & $(0.000)$ & $(0.000)$ & $(0.596)$ & $(0.066)$ & $(0.934)$ & $(0.000)$ & $(0.024)$ & $(0.026)$ & & \\
\hline
\end{tabular}


Table 4 (continued): Impact of firm-specific variables on leverage across countries

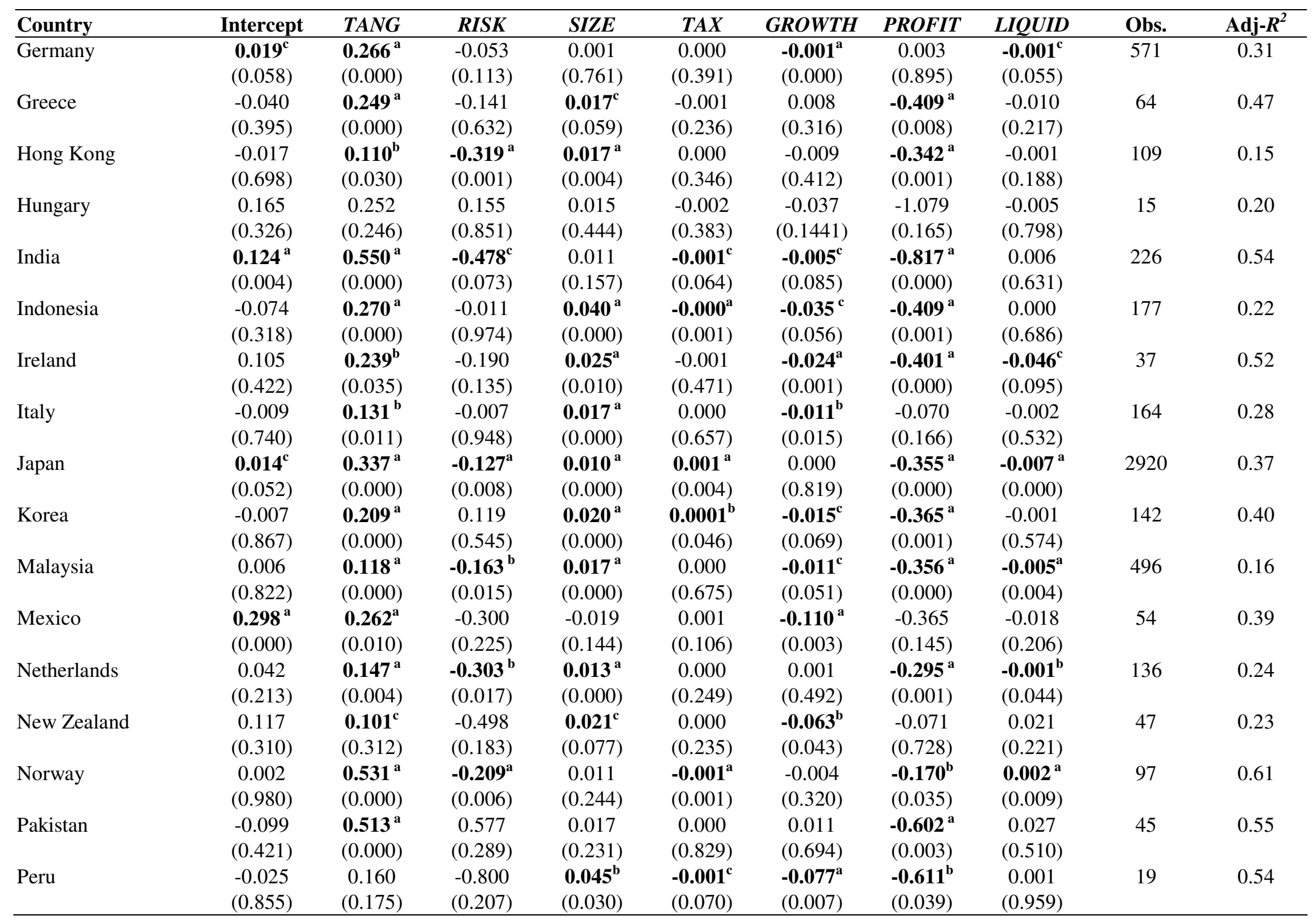


Table 4 (continued): Impact of firm-specific variables on leverage across countries

\begin{tabular}{|c|c|c|c|c|c|c|c|c|c|c|}
\hline Country & Intercept & $T A N G$ & RISK & SIZE & $T A X$ & GROWTH & PROFIT & LIQUID & Obs. & $\operatorname{Adj}-R^{2}$ \\
\hline \multirow[t]{2}{*}{ Philippines } & $0.115^{b}$ & 0.040 & 0.049 & 0.000 & 0.000 & $-0.001^{a}$ & 0.106 & -0.001 & 77 & 0.03 \\
\hline & $(0.027)$ & $(0.666)$ & $(0.763)$ & (0.989) & $(0.933)$ & $(0.000)$ & $(0.653)$ & $(0.145)$ & & \\
\hline \multirow[t]{2}{*}{ Poland } & 0.063 & -0.021 & 0.142 & 0.009 & 0.000 & -0.026 & 0.118 & $-0.021^{c}$ & 23 & 0.10 \\
\hline & $(0.478)$ & $(0.779)$ & $(0.757)$ & $(0.514)$ & $(0.758)$ & $(0.203)$ & $(0.651)$ & $(0.095)$ & & \\
\hline \multirow[t]{2}{*}{ Portugal } & 0.068 & $0.166^{b}$ & $-0.974^{c}$ & 0.014 & 0.000 & $-0.015^{b}$ & -0.525 & 0.024 & 31 & 0.26 \\
\hline & $(0.618)$ & $(0.063)$ & $(0.076)$ & $(0.298)$ & $(0.273)$ & $(0.014)$ & $(0.127)$ & $(0.503)$ & & \\
\hline \multirow[t]{2}{*}{ Singapore } & 0.054 & $0.168^{a}$ & -0.122 & $0.013^{b}$ & 0.000 & $-0.030^{a}$ & $-0.214^{a}$ & $-0.009^{c}$ & 310 & 0.23 \\
\hline & $(0.197)$ & $(0.000)$ & $(0.153)$ & $(0.016)$ & $(0.555)$ & $(0.000)$ & $(0.000)$ & $(0.053)$ & & \\
\hline \multirow[t]{2}{*}{ Spain } & 0.038 & $0.183^{a}$ & 0.028 & 0.010 & 0.000 & -0.006 & $-0.377^{b}$ & -0.001 & 92 & 0.24 \\
\hline & $(0.510)$ & $(0.001)$ & (0.939) & $(0.135)$ & $(0.517)$ & $(0.414)$ & $(0.026)$ & $(0.963)$ & & \\
\hline \multirow[t]{2}{*}{ Sweden } & $0.099^{a}$ & $0.339^{a}$ & $-0.173^{a}$ & 0.000 & $-0.0003^{c}$ & $-0.015^{a}$ & $-0.075^{b}$ & $-0.003^{c}$ & 206 & 0.38 \\
\hline & $(0.005)$ & $(0.000)$ & $(0.002)$ & $(0.955)$ & $(0.083)$ & $(0.000)$ & $(0.045)$ & $(0.077)$ & & \\
\hline \multirow[t]{2}{*}{ Switzerland } & $0.152^{a}$ & $0.302^{a}$ & $-0.229^{c}$ & -0.009 & 0.000 & $-0.013^{b}$ & -0.090 & $-0.006^{c}$ & 164 & 0.41 \\
\hline & $(0.001)$ & $(0.000)$ & $(0.056)$ & $(0.172)$ & $(0.271)$ & $(0.015)$ & $(0.299)$ & $(0.076)$ & & \\
\hline Taiwan & $(0.046)$ & $(0.000)$ & $(0.452)$ & $(0.000)$ & $(0.231)$ & $(0.001)$ & $(0.045)$ & $(0.824)$ & & \\
\hline \multirow[t]{2}{*}{ Thailand } & -0.057 & $0.228^{a}$ & $-0.499^{c}$ & $0.029^{a}$ & $-0.002^{a}$ & 0.010 & $-0.538^{a}$ & -0.005 & 244 & 0.23 \\
\hline & $(0.448)$ & $(0.000)$ & $(0.077)$ & $(0.001)$ & $(0.006)$ & $(0.526)$ & $(0.000)$ & $(0.470)$ & & \\
\hline \multirow[t]{2}{*}{ Turkey } & 0.146 & $0.167^{\mathrm{c}}$ & 0.148 & $-0.016^{c}$ & 0.000 & -0.001 & -0.144 & -0.024 & 39 & 0.13 \\
\hline & $(0.185)$ & $(0.067)$ & $(0.375)$ & $(0.357)$ & $(0.857)$ & $(0.830)$ & $(0.112)$ & $(0.262)$ & & \\
\hline \multirow[t]{2}{*}{ UK } & -0.007 & $0.170^{a}$ & -0.033 & $0.012^{a}$ & 0.000 & $-0.004^{a}$ & $-0.086^{a}$ & 0.000 & 795 & 0.31 \\
\hline & $(0.505)$ & $(0.000)$ & $(0.227)$ & $(0.000)$ & $(0.611)$ & $(0.006)$ & $(0.000)$ & $(0.352)$ & & \\
\hline \multirow[t]{2}{*}{ US } & $0.095^{a}$ & $0.239^{a}$ & $-0.181^{a}$ & $0.008^{a}$ & 0.000 & $-0.012^{a}$ & $-0.142^{a}$ & $-0.003^{b}$ & 2533 & 0.30 \\
\hline & $(0.000)$ & $(0.000)$ & $(0.000)$ & $(0.000)$ & $(0.204)$ & $(0.000)$ & $(0.000)$ & $(0.043)$ & & \\
\hline
\end{tabular}




\section{Table 5: $F$-test for the equality of coefficients of firm-specific determinants across countries}

This table presents the test results of the null hypotheses that each of the firm-specific coefficients is the same across countries (hypotheses ECl to EC7), and also the null hypothesis that all firm-specific coefficients of 42 countries have the same value (hypothesis EC8). The test statistic is $f=\frac{\left(S_{R}-S_{U R}\right) / J}{S_{U R} /(N-K)}$ where $N$ is the number of observations, $J$ is the number of regressors omitted in the restricted models, $K$ is the number of regressors remaining in the restricted models including the intercept, and $S_{R}$ and $S_{U R}$ denote the sum-squared-residuals of the restricted (equal coefficients are imposed) and unrestricted (coefficients may differ across countries) models, respectively. Using the Seemingly Unrelated Regression (SUR) estimation method, we get $S_{U R}$ by adding all sum-squared-residuals (SSR) from all the equations for firm-specific determinants of leverage (as specified in Equation (1)). For $S_{R}$ in each test (still using SUR), we add the SSR from the restricted equations in the system with respective assumption that the relevant coefficients are the same across countries. Rejection means the null hypothesis is rejected at $5 \%$ level.

\begin{tabular}{lcccccccc}
\hline & TANG & RISK & SIZE & TAX & GROWTH & PROFIT & LIQUID & ALL \\
\hline$f$-statistic & 7.290 & 1.165 & 3.676 & 1.551 & 8.773 & 4.369 & 2.305 & 5.383 \\
$p$-value & 0.000 & 0.218 & 0.000 & 0.014 & 0.000 & 0.000 & 0.000 & 0.000 \\
$N$ & 11834 & 11834 & 11834 & 11834 & 11834 & 11834 & 11834 & 11834 \\
$K$ & 295 & 295 & 295 & 295 & 295 & 295 & 295 & 49 \\
$J$ & 41 & 41 & 41 & 41 & 41 & 41 & 287 \\
$R$ & Rejection & No rejection & Rejection & Rejection & Rejection & Rejection & Rejection & Rejection \\
\hline
\end{tabular}


Table 6: Direct impact of country-specific variables on leverage

This table presents the WLS regression results of country dummy coefficients ( $\left.\hat{\alpha}_{j}\right)$ against country-specific factors estimated from Equation (3):

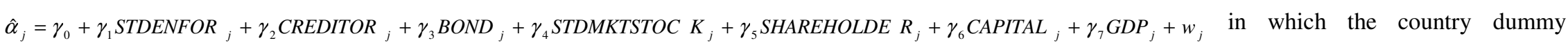
coefficients are reported in Table 4 (intercept). All country-specific variables are defined in Table 2 . The weights are inverse standard errors of the corresponding country dummy coefficients estimated from Equation (2). The significant coefficients are printed in bold with $p$-values in parentheses. The superscripts a, b, and c indicate statistical significance at the $1 \%, 5 \%$ and $10 \%$ level, respectively. The number of observations is 37 , which are the countries that have all countryspecific variables available. Adj- $R^{2}$ is the value of adjusted- $R^{2}$ for the regression.

\begin{tabular}{|c|c|c|c|c|c|c|c|c|c|}
\hline \multirow{2}{*}{$\begin{array}{l}\text { Dependent } \\
\text { variable }\end{array}$} & \multicolumn{8}{|c|}{ Explanatory variables } & \multirow[t]{2}{*}{$\operatorname{Adj}-R^{2}$} \\
\hline & Intercept & STDENFOR & CREDITOR & BOND & STDMKTSTOCK & SHAREHODLER & CAPITAL & $G D P$ & \\
\hline \multirow[t]{10}{*}{ COUNTRYDUM } & 0.0051 & -0.0176 & $-0.0164^{a}$ & 0.0368 & 0.0036 & -0.0032 & 0.0271 & $0.0200^{a}$ & 0.54 \\
\hline & $(0.9247)$ & $(0.1337)$ & $(0.0070)$ & $(0.1224)$ & $(0.7083)$ & $(0.5443)$ & $(0.8807)$ & $(0.0062)$ & \\
\hline & 0.0106 & -0.0178 & $-0.0163^{a}$ & 0.0373 & 0.0031 & -0.0031 & & $0.0199^{a}$ & 0.55 \\
\hline & $(0.7888)$ & $(0.1219)$ & $(0.0061)$ & $(0.1089)$ & $(0.7269)$ & $(0.5483)$ & & $(0.0053)$ & \\
\hline & 0.0025 & -0.0181 & $-0.0161^{a}$ & $0.0400^{c}$ & & -0.0026 & & $0.0215^{a}$ & 0.56 \\
\hline & $(0.9364)$ & $(0.1089)$ & $(0.0057)$ & $(0.0649)$ & & $(0.5964)$ & & $(0.0001)$ & \\
\hline & 0.0016 & -0.0181 & $-0.0161^{a}$ & $0.0400^{c}$ & & -0.0026 & 0.0036 & $0.0215^{a}$ & 0.55 \\
\hline & $(0.9755)$ & $(0.1159)$ & $(0.0066)$ & $(0.0695)$ & & $(0.6021)$ & $(0.9827)$ & $(0.0003)$ & \\
\hline & -0.0015 & $-0.0189^{c}$ & $-0.0165^{a}$ & $0.0374^{c}$ & & & & $0.0206^{\mathrm{a}}$ & 0.57 \\
\hline & $(0.9621)$ & $(0.0889)$ & $(0.0039)$ & $(0.0720)$ & & & & $(0.0000)$ & \\
\hline
\end{tabular}


Table 7: Indirect impact of country-specific variables on leverage

This table presents the WLS regression results of coefficients of firm-specific variables ( $\hat{\beta}_{k j}$ estimated from Equation 1 and reported in Table 4 ) against countryspecific variables, estimated from Equation (4):

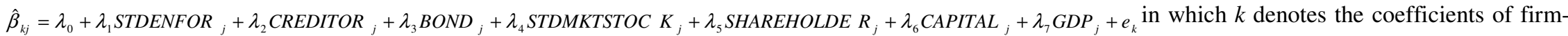
specific factors and $j$ denotes a country. All country-specific variables are defined in Table 2 . The weights are inverse standard errors of the corresponding country dummy coefficients estimated in Equation (2). The significant coefficients are printed in bold with $p$-values in parentheses. The superscripts a, $\mathrm{b}$, and c indicate statistical significance at the $1 \%, 5 \%$ and $10 \%$ level, respectively. The number of observations is 37 , which are the countries that have all countryspecific variables available. Adj- $R^{2}$ is the value of adjusted- $R^{2}$ for the regression.

\begin{tabular}{|c|c|c|c|c|c|c|c|c|c|}
\hline \multirow{2}{*}{$\begin{array}{l}\text { Dependent } \\
\text { variable }\end{array}$} & \multicolumn{8}{|c|}{ Explanatory variables } & \multirow[t]{2}{*}{$\operatorname{Adj}-R^{2}$} \\
\hline & Intercept & STDENFOR & CREDITOR & BOND & STDMKTSTOCK & SHAREHODLER & CAPITAL & $G D P$ & \\
\hline \multirow[t]{8}{*}{ TANG } & $0.1990^{c}$ & -0.0042 & -0.0091 & 0.0525 & $-0.0465^{b}$ & 0.0118 & 0.0396 & -0.0081 & 0.13 \\
\hline & $(0.0995)$ & $(0.8739)$ & $(0.5138)$ & $(0.2937)$ & $(0.0383)$ & $(0.4082)$ & $(0.9213)$ & $(0.5660)$ & \\
\hline & $0.2068^{b}$ & -0.0044 & -0.0089 & 0.0531 & $-0.0473^{b}$ & 0.0118 & & -0.0081 & 0.16 \\
\hline & $(0.0217)$ & $(0.8659)$ & $(0.5109)$ & $(0.2765)$ & $(0.0242)$ & $(0.3974)$ & & $(0.5609)$ & \\
\hline & $0.2125^{a}$ & & -0.0090 & 0.0490 & $-0.0466^{b}$ & 0.0112 & & -0.0087 & 0.19 \\
\hline & $(0.0100)$ & & $(0.4947)$ & $(0.2387)$ & $(0.0215)$ & $(0.3973)$ & & $(0.5153)$ & \\
\hline & $0.1857^{a}$ & & -0.0068 & 0.0596 & $-0.0532^{a}$ & 0.0092 & & & 0.20 \\
\hline & $(0.0077)$ & & $(0.5909)$ & $(0.1179)$ & $(0.0026)$ & $(0.4701)$ & & & \\
\hline \multirow[t]{8}{*}{ RISK } & 0.0513 & -0.0370 & 0.0229 & 0.0389 & -0.0460 & -0.0018 & $-1.0630^{b}$ & 0.0063 & 0.12 \\
\hline & $(0.6950)$ & $(0.2490)$ & $(0.1301)$ & $(0.5183)$ & $(0.1442)$ & $(0.9165)$ & $(0.0209)$ & $(0.7539)$ & \\
\hline & 0.0463 & -0.0374 & 0.0227 & 0.0392 & -0.0476 & & $-1.0608^{b}$ & 0.0058 & 0.14 \\
\hline & $(0.6988)$ & $(0.2315)$ & $(0.1243)$ & $(0.5076)$ & $(0.0773)$ & & $(0.0189)$ & $(0.7616)$ & \\
\hline & 0.0634 & -0.0349 & 0.0209 & 0.0308 & $-0.0434^{c}$ & & $-1.0246^{b}$ & & 0.17 \\
\hline & $(0.5415)$ & $(0.2392)$ & $(0.1151)$ & $(0.5492)$ & $(0.0553)$ & & $(0.0167)$ & & \\
\hline & 0.0908 & -0.0282 & 0.0172 & & $-0.0374^{c}$ & & $-1.0202^{b}$ & & 0.19 \\
\hline & $(0.3277)$ & $(0.2976)$ & $(0.1354)$ & & $(0.0602)$ & & $(0.0159)$ & & \\
\hline \multirow[t]{8}{*}{ SIZE } & -0.0031 & -0.0040 & 0.0011 & -0.0029 & 0.0002 & $0.0024^{b}$ & 0.0305 & 0.0001 & 0.17 \\
\hline & $(0.7690)$ & $(0.1027)$ & $(0.3581)$ & $(0.5183)$ & $(0.9217)$ & $(0.0346)$ & $(0.4086)$ & $(0.9312)$ & \\
\hline & -0.0026 & $-0.0040^{c}$ & 0.0010 & -0.0030 & 0.0003 & $0.0024^{b}$ & 0.0303 & & 0.19 \\
\hline & $(0.7650)$ & $(0.0941)$ & $(0.3382)$ & $(0.4287)$ & $(0.8618)$ & $(0.0308)$ & $(0.4028)$ & & \\
\hline & -0.0023 & $-0.0040^{c}$ & 0.0011 & -0.0029 & & $0.0025^{b}$ & 0.0274 & & 0.22 \\
\hline & $(0.7841)$ & $(0.0861)$ & $(0.3285)$ & $(0.4314)$ & & $(0.0106)$ & $(0.3856)$ & & \\
\hline & -0.0044 & $-0.0049^{b}$ & 0.0014 & & & $0.0024^{b}$ & 0.0244 & & 0.23 \\
\hline & $(0.5806)$ & $(0.0192)$ & $(0.1462)$ & & & $(0.0120)$ & $(0.4321)$ & & \\
\hline
\end{tabular}


Table 7 (continued): Indirect impact of country-specific variables on leverage

\begin{tabular}{|c|c|c|c|c|c|c|c|c|c|}
\hline \multirow{2}{*}{$\begin{array}{l}\text { Dependent } \\
\text { variable }\end{array}$} & \multicolumn{8}{|c|}{ Explanatory variables } & \multirow[t]{2}{*}{ Adj-R } \\
\hline & Intercept & STDENFOR & CREDITOR & BOND & STDMKTSTOCK & SHAREHODLER & CAPITAL & $G D P$ & \\
\hline \multirow[t]{6}{*}{ GROWTH } & 0.0056 & -0.0010 & 0.0000 & -0.0034 & -0.0014 & -0.0005 & 0.0071 & $-0.0024^{b}$ & 0.58 \\
\hline & $(0.5748)$ & $(0.5203)$ & $(0.9635)$ & $(0.4128)$ & $(0.4561)$ & $(0.4003)$ & $(0.8657)$ & $(0.0442)$ & \\
\hline & 0.0058 & -0.0010 & & -0.0034 & -0.0014 & -0.0005 & 0.0069 & $-0.0024^{b}$ & 0.60 \\
\hline & $(0.5121)$ & $(0.3418)$ & & $(0.3595)$ & $(0.4382)$ & $(0.3789)$ & $(0.8663)$ & $(0.0395)$ & \\
\hline & 0.0070 & -0.0010 & & -0.0033 & -0.0016 & -0.0005 & & $-0.0024^{b}$ & 0.61 \\
\hline & $(0.1453)$ & $(0.3250)$ & & $(0.3572)$ & $(0.2893)$ & $(0.2781)$ & & $(0.0296)$ & \\
\hline \multirow[t]{8}{*}{ PROFIT } & $0.3167^{c}$ & $0.1066^{a}$ & 0.0052 & -0.0039 & 0.0304 & $-0.05033^{a}$ & $-1.8531^{a}$ & 0.0034 & 0.44 \\
\hline & $(0.0503)$ & $(0.0063)$ & $(0.7688)$ & $(0.9521)$ & $(0.3230)$ & $(0.0054)$ & $(0.0019)$ & $(0.8612)$ & \\
\hline & $0.3119^{b}$ & $0.1056^{a}$ & 0.0057 & & 0.0295 & $-0.0502^{a}$ & $-1.8562^{a}$ & 0.0039 & 0.46 \\
\hline & $(0.0242)$ & $(0.0021)$ & $(0.6918)$ & & $(0.2672)$ & $(0.0046)$ & $(0.0015)$ & $(0.8176)$ & \\
\hline & $0.3187^{b}$ & $0.1062^{a}$ & 0.0053 & & 0.0309 & $-0.0495^{a}$ & $-1.8501^{a}$ & & 0.48 \\
\hline & $(0.0169)$ & $(0.0016)$ & $(0.7077)$ & & $(0.2264)$ & $(0.0039)$ & $(0.0013)$ & & \\
\hline & $0.3271^{b}$ & $0.1043^{a}$ & & & 0.0291 & $-0.0496^{a}$ & $-1.8309^{a}$ & & 0.49 \\
\hline & $(0.0118)$ & $(0.0014)$ & & & $(0.2389)$ & $(0.0034)$ & $(0.0012)$ & & \\
\hline \multirow[t]{6}{*}{ LIQUID } & $0.0079^{b}$ & $0.0014^{a}$ & -0.0001 & $-0.0052^{a}$ & -0.0004 & -0.0002 & $-0.0257^{b}$ & 0.0004 & 0.53 \\
\hline & $(0.0414)$ & $(0.0048)$ & $(0.7183)$ & $(0.0002)$ & $(0.5620)$ & $(0.3601)$ & $(0.0195)$ & $(0.4973)$ & \\
\hline & $0.0069^{a}$ & $0.0013^{a}$ & & $-0.0050^{a}$ & -0.0005 & -0.0002 & $-0.0249^{b}$ & 0.0005 & 0.55 \\
\hline & $(0.0090)$ & $(0.0005)$ & & $(0.0000)$ & $(0.3568)$ & $(0.3815)$ & $(0.0186)$ & $(0.1635)$ & \\
\hline & $0.0062^{b}$ & $0.0011^{a}$ & & $-0.0047^{a}$ & -0.0007 & & $-0.0255^{b}$ & 0.0005 & 0.55 \\
\hline & $(0.0124)$ & $(0.0005)$ & & $(0.0000)$ & $(0.1580)$ & & $(0.0153)$ & $(0.1894)$ & \\
\hline
\end{tabular}




\section{Publications in the Report Series Research ${ }^{*}$ in Management}

\section{ERIM Research Program: "Finance and Accounting"}

2007

Revisiting Uncovered Interest Rate Parity: Switching Between UIP and the Random Walk

Ronald Huisman and Ronald Mahieu

ERS-2007-001-F\&A

http://hdl.handle.net/1765/8288

Hourly Electricity Prices in Day-Ahead Markets

Ronald Huisman, Christian Huurman and Ronald Mahieu

ERS-2007-002-F\&A

http://hdl.handle.net/1765/8289

Do Exchange Rates Move in Line with Uncovered Interest Parity?

Ronald Huisman, Ronald Mahieu and Arjen Mulder

ERS-2007-012-F\&A

http://hdl.handle.net/1765/8993

Hedging Exposure to Electricity Price Risk in a Value at Risk Framework

Ronald Huisman, Ronald Mahieu and Felix Schlichter

ERS-2007-013-F\&A

http://hdl.handle.net/1765/8995

Corporate Governance and Acquisitions: Acquirer Wealth Effects in the Netherlands

Abe de Jong, Marieke van der Poel and Michiel Wolfswinkel

ERS-2007-016-F\&A

$\underline{\text { http://hdl.handle.net/1765/9403 }}$

The Effect of Monetary Policy on Exchange Rates during Currency Crises; The Role of Debt, Institutions and Financial Openness

Sylvester C.W. Eijffinger and Benedikt Goderis

ERS-2007-022-F\&A

http://hdl.handle.net/1765/9725

Do Private Equity Investors Take Firms Private for Different Reasons?

Jana P. Fidrmuc, Peter Roosenboom and Dick van Dijk

ERS-2007-028-F\&A

http://hdl.handle.net/1765/10070

The Influence of Temperature on Spike Probability in Day-Ahead Power Prices

Ronald Huisman

ERS-2007-039-F\&A

http://hdl.handle.net/1765/10179

Costs and Recovery Rates in the Dutch Liquidation-Based Bankruptcy System

Oscar Couwenberg and Abe de Jong

ERS-2007-041-F\&A

http://hdl.handle.net/1765/10461

The Volatility Effect: Lower Risk without Lower Return

David C. Blitz and Pim van Vliet

ERS-2007-044-F\&A

http://hdl.handle.net/1765/10460 
Strategic Debt: Evidence from Bertrand and Cournot Competition

Abe de Jong, Thuy Thu Nguyen and Mathijs A. van Dijk

ERS-2007-057-F\&A

Capital Structure Around the World: The Roles of Firm- and Country-Specific Determinants Abe de Jong, Rezaul Kabir and Thuy Thu Nguyen

ERS-2007-058-F\&A

* A complete overview of the ERIM Report Series Research in Management: https://ep.eur.nl/handle/1765/1

ERIM Research Programs:

LIS Business Processes, Logistics and Information Systems

ORG Organizing for Performance

MKT Marketing

F\&A Finance and Accounting

STR Strategy and Entrepreneurship 